\title{
WAGING WAR WITHIN THE CONSTITUTION
}

\author{
Alberto R. Gonzales*
}

\begin{abstract}
This Article examines the United States' response to the September 11, 2001 attacks by al Qaeda from my perspective as Counsel to the President and then later as Attorney General. It reviews the actions of government lawyers and how federal courts have judged the implementation of U.S. government policy. ${ }^{1}$ It explains that U.S. government officials quickly understood that our nation was confronted with a non-state enemy fighting an unconventional war. ${ }^{2}$ This forced us to make a number of difficult decisions quickly about how best to fight this threat in a manner consistent with the United States' domestic and international legal obligations. ${ }^{3}$ Soon following the attacks, President George W. Bush and the U.S. Congress determined, in essence, that the actions against the United States were more than crimes. ${ }^{4}$

The Authorization for the Use of Military Force, passed by Congress on September 18,2001, reflected a belief that the murder of over 3,000 innocent Americans constituted an act of military aggression against the United States. ${ }^{5}$ In the months following the September 11, 2001 attacks, the U.S. government declared that, as a matter of law: (1) the Geneva Conventions did not apply to the conflict between the United States and al Qaeda and (2) members of al Qaeda and the Taliban were not entitled to prisoner of war protections under the Geneva Conventions. ${ }^{6}$ These actions formed the foundation of subsequent decisions, including the detention policy at Guantanamo Bay, Cuba. ${ }^{7}$ There were, at times, strong and differing views within the Bush Administration and Congress about these issues. ${ }^{8}$
\end{abstract}

* Former Counsel to the President and United States Attomey General under the George W. Bush Administration. Before joining the Bush Administration in Washington, he served as then-Governor George W. Bush's General Counsel, then Texas Secretary of State, and was later appointed to the Texas Supreme Court. He is currently a visiting professor at Texas Tech University.

1. See Part V.

2. See Part I.

3. See Part I.

4. See Part I.

5. See Part I.

6. See Part I.

7. See Parts I-II.

8. See Parts I-II. 
This Article examines the competing views of law and policy and the processes that led to the recommendations informing these decisions. ${ }^{9}$ Not surprisingly, decisions like the presidential determination of enemy combatant status, limits on the rights of Guantanamo detainees to challenge their detention in U.S. federal courts, and the promulgation of military commission procedures were challenged in our courts. ${ }^{10}$ Finding the appropriate balance between the protection of our national security and of our civil liberties is one of the most difficult duties of our government. According to the courts, the U.S. government struck the correct balance in certain instances. ${ }^{11}$ In other cases, the courts found the government had not. ${ }^{12}$ This Article reviews the U.S. government's legal positions in the major terrorism cases, as well as the Supreme Court Justices' obvious struggle with these issues. ${ }^{13}$ During other periods of national conflict or emergency, such as World War II, the Supreme Court has been particularly deferential to the elected branches of government with respect to government action outside U.S. territory that did not involve U.S. citizens. ${ }^{14}$ The most recent court decisions, however, demonstrate that at least certain members of the Supreme Court have decided the Court should now play a more significant role in decisions that the Court, at times, left to the discretion and judgment of the President and Congress. ${ }^{15}$

\section{WAGING WAR WITHIN THE CONSTITUTION ${ }^{16}$}

On September 11, 2001, the United States suffered a devastating attack that changed our way of life and refocused the Bush Administration's priorities. ${ }^{17}$ People in Europe and the Middle East have lived with terrorism within their homelands for decades. ${ }^{18}$ For many overseas, terrorist attacks are a sad reality of life. Until the September 11 th attacks, most Americans had never felt the personal pain of terrorism's sting. ${ }^{19}$ Even our government leaders had failed to acknowledge, or fully appreciate, terrorism as a realistic threat to

\footnotetext{
9. See Parts I-VI.

10. See Parts V-VI.

11. See Parts V-VI

12. See Parts V-VI.

13. See Parts V-VI.

14. See Parts V-VI.

15. See Parts V.VI.

16. I thank Mallory Beagles and Jordan Miller for their helpful comments and assistance.

17. See Nancy Gibbs, 9/11: One Year Later: What a Difference a Day Makes, TME, Sept. 1, 2002, at 20.

18. See Amaud Blin, The United States Confronting Terrorism, in THE HISTORY OF TERRORISM: FroM ANTIQUITY TO AL QAEDA 398-99 (Gerard Chaliand \& Arnaud Blin eds., Edward Schneider, Kathryn Pulver \& Jesse Browner trans.) (2007).

19. See generally Claudia Kalb \& Aku Ammah-Tagoe, Generation 9/11: Children Who Watched the Tragedy Unfold Are Now on the Brink of Adulthood, NEWSWEEK, Sept. 8, 2009, http://www.newsweek.com/ id/215044 (describing the impact of the September 11th attacks on the largely sheltered "millennial" generation).
} 
America despite the 1993 World Trade Center bombing, the 1996 Khobar Towers bombing, the 1998 American embassies bombings in Kenya and Tanzania, and the 2000 USS Cole bombing. ${ }^{20}$

Immediately following the September 11 th attacks, U.S. government officials made the fundamental decision to treat the attacks on our country not simply as criminal acts - though they certainly were - but as acts of war. ${ }^{21} \mathrm{~A}$ mere law enforcement response would have focused solely on gathering evidence against those involved, arresting them, interviewing witnesses, convening grand juries, and preparing cases for civilian prosecutions. ${ }^{22}$ President George W. Bush strongly believed our government needed to do something more. ${ }^{23}$ In order to defend the security of our citizens, President Bush decided that our government needed the ability to detain and remove the enemy from the battlefield, just as the United States has in other wars. ${ }^{24}$ The U.S. government needed to collect vital intelligence from apprehended terrorists in order to capture their associates and break up future terrorist plots. ${ }^{25}$ The U.S. government also needed to create effective and fair procedures in order to hold terrorists accountable for war crimes. ${ }^{26}$

Congress did not formally declare war under Article I, $\S 7$ of the Constitution; however, on September 18, 2001, members overwhelmingly passed the Authorization for Use of Military Force (AUMF) ${ }^{27}$ In this AUMF, Congress did two important things. ${ }^{28}$ First, it expressly recognized the President's "authority under the Constitution to take action to deter and prevent acts of international terrorism against the United States." ${ }^{29}$ Second, it supplemented that authority by authorizing the President to "use all necessary and appropriate force against those nations, organizations, or persons he determines planned, authorized, committed, or aided the terrorist attacks" in order to prevent future attacks on the United States. ${ }^{30}$ Consequently, our government applied a different legal framework than the one used during peacetime criminal investigations and prosecutions. ${ }^{31}$ This framework, the law

20. See Gerard Chaliand \& Amaud Blin, From 1968 to Radical Islam, in THE HISTORY OF TERRORISM: FROM ANTIQUITY TO AL QAEDA, supra note 18, at 223; Francois Géré, Suicide Operations: Between War and Terrorism, in THE HISTORY OF TERRORISM: FROM ANTIQUITY TO AL QAEDA, supra note 18, at 383-84.

21. See JOHN YOO, WAR BY OTHER MEANS: AN INSIDER'S ACCOUNT OF THE WAR ON TERROR 2, 8-15 (2006).

22. Alberto Gonzales, U.S. Attorney Gen., Address to the U.S. Coast Guard Academy at New London, Connecticut (Sept. 6, 2007), http://www.justice.gov/archive/ag/speeches/2007/ag_speech_070906.html.

23. See YOO, supra note 21 , at 10-12.

24. See PETER S. LATHAM \& PATRICIA H. LATHAM, TERRORISM AND THE LAW: BRINGING TERRORISTS TO JUSTICE 23-31 (2002).

25. See YoO, supra note 21 , at 172.

26. Detention, Treatment, and Trial of Certain Non-Citizens in the War Against Terrorism, 66 Fed. Reg. 57833 (Nov. 13, 2001).

27. Authorization for Use of Military Force, Pub. L. No. 107-40, 115 Stat. 224 (2001).

28. See id.

29. Id.

30. Id.

31. See id. 
of armed conflict, included the well-established custom of detaining enemy combatants indefinitely without charges for the duration of hostilities. ${ }^{32}$ Detention is critical in securing a nation and its citizens-it keeps combatants off the battlefield and helps disrupt the plans of the combatants who are still on that battlefield. ${ }^{33}$

From the outset, our government endeavored to maintain a clear distinction between our criminal justice system and our law of armed conflict framework for treatment and prosecution of terrorists. ${ }^{34}$ The strategy was to keep the two separate in order to encourage the courts to respect the integrity of both systems, particularly the authority of the Commander in Chief to detain unlawful enemy combatants without charges for the duration of hostilities. ${ }^{35}$

The United States' conflict with al Qaeda and the Taliban triggered a number of novel legal questions virtually unprecedented in terms of difficulty and controversy. It is important for the reader to understand how I viewed my role as Counsel to the President during this period of the early months when officials feared another terrorist attack was imminent. I supervised a staff of twelve of the most talented and dedicated lawyers you would expect to serve a President. As Counsel, I served both as a lawyer for the presidency and as a client-much like a general counsel of a company. Every government agency engaged in the fight against terrorism-including, for example, the Department of Defense, Department of State, Department of Justice, Department of the Treasury, and the Central Intelligence Agency - has its own legal staff. ${ }^{36}$ Most agencies have a general counsel who is a political appointee. ${ }^{37}$ The general counsel supervises the staff of career lawyers who are experts in the legal issues arising before that particular agency. ${ }^{38}$ The career legal staff possesses the institutional legal memory for that agency. They provide daily legal advice to the general counsel and for their agency on a host of routine legal questions without ever consulting the White House or the Department of Justice. ${ }^{39}$ The career lawyers - both military and civilian - support the work and legal advice of their general counsels. I interacted primarily with the general counsels and other political appointees. I did not do this to cut off conflicting advice or avoid hearing dissenting opinions. I did so as a matter of custom and prudence. By limiting my contacts with career lawyers, I was able to minimize the appearance of the White House placing political pressure on career lawyers.

32. See YoO, supra note 21 , at 11-13, 128-30.

33. Gonzales, Address to the U.S. Coast Guard Academy, supra note 22.

34. See YoO, supra note 21 , at 11-13, 128-30.

35. See id.

36. See Dep't of Def.: Office of the Gen. Counsel, http://www.dod.gov/dodgc/; Dep't of State: Office of Gen. Counsel, http://oig.state.gov/c7824.htm; Dep't of Justice: Office of Legal Counsel, http://www.justice. gov/old; Dep't of the Treasury: Office of Gen. Counsel, http://www.ustreas.gov/offices/general-counsel/; Cent. Intelligence Agency: Gen. Counsel, https:/www.cia.gov/offices-of-cia/general-counsel/index.html.

37. See U.S. CoNST. art. II, § 2, cl. 2.

38. See, e.g., Dep't of Def.: Office of the Gen. Counsel, http://www.dod.gov/dodgc/about.html.

39. See, e.g., id. 
Whenever a legal issue affected multiple agencies or touched upon the statutory or constitutional powers of the President, I expected the White House Counsel's Office to be consulted, and we were often involved, in varying degrees, in the disposition of such issues. In these cases, I would often invite the general counsels from the affected agencies to my office in the West Wing of the White House to discuss the issue and, additionally, I would work with lawyers from the Department of Justice as we sought consensus on the legal questions.

Not surprisingly, the lawyers sometimes disagreed. I respected the legal abilities and patriotism of all the lawyers I dealt with serving in the Executive Branch, and I valued candid discussions and honest disagreements, but the Executive Branch required one definitive legal position. I determined at the outset of my tenure that the final word should come from the Department of Justice because the Attorney General is charged by statute to interpret the law for the Executive Branch. ${ }^{40} \mathrm{He}$ has, in turn, delegated this responsibility to the Office of Legal Counsel (OLC), a collection of some of the finest legal minds in our government. ${ }^{41}$ OLC's interpretation of the law is definitive. ${ }^{42}$ OLC has traditionally served as the law firm for the President and the Attorney General, but, unlike most law firms, I did not view OLC's role to be one of advocate to the President's powers. Nor did I expect OLC to advance whatever arguments it could to support a Presidential decision. I expected OLC to exercise independent judgment on the law. ${ }^{43}$ Informed by the views of the other agencies, OLC would best serve the President in providing legal opinions on the major terrorism questions, for after all, the Department of Justice would have to defend the Executive Branch's legal position in our courts.

Because I did not have the institutional memory of the agency lawyers or the expertise of the Department of Justice lawyers, I did not view my role as Counsel to the President as the decider of these difficult legal questions for the Executive Branch. My role was to help ensure that the appropriate peoplethose with the appropriate level of responsibility and the relevant experience and understanding of the issues-provided their views to the Department of Justice so that the lawyers at OLC could reach the correct legal conclusionone that was informed and defendable in the courts. I am not saying I did not comment or offer my views. I sometimes did. I am an accomplished lawyer and a former Texas Supreme Court jurist, but I was also a client. Mindful of the perception that I had the President's ear, I often purposefully withheld my opinion in order to encourage candid discussions between the lawyers. Perhaps because of my experience as a judge, I preferred to listen to all sides of an argument before reaching a conclusion. Sometimes I asked questions; often I

\footnotetext{
40. See Judiciary Act of 1789 , ch. XX, $\S 35,1$ Stat. 73 .

41. See United States Dep't of Justice: Office of the Attorney Gen., http://www.justice.gov/olc/.

42. See JACK GOLDSMITH, THE TERROR PRESIDENCY 96-97 (2007).

43. See YOO, supra note 21 , at $185-87$.
} 
did not. Sometimes after a briefing, I would direct one of the lawyers on my staff to conduct additional research on issues that continued to trouble me. If asked - and sometimes when not asked - I directly shared my own views of the law with the President. But I always strived to be an honest broker by presenting faithfully the Department of Justice's legal position as well as any strong differing views.

Like previous Administrations, the Bush Administration developed policy through formal and informal processes. At times we used a formal interagency process that relied on the collaborative work of policy experts and cabinet and deputy secretaries. Sometimes on more sensitive issues, a smaller group of advisers would work to develop strategies to help protect America. I tried as best as I could not to allow my morals, religious beliefs, or personal views on policy to influence my interpretation of the law. I expected the same fidelity from the other lawyers providing legal advice. I believe the President of the United States and other Executive Branch policy makers deserve a lawyer's best judgment of the law, unfettered by that lawyer's policy views. It is as unconscionable and unforgiveable for a lawyer to shade his legal advice because of his views on policy as it would be for a judge to allow his policy views to affect his interpretation of the law. On some occasions, President Bush would ask for my personal view on policy and I would give it to him, but I always tried to make it clear to him when I was answering a question as a matter of law and when I was offering an opinion on policy.

I.

Once the government determined the United States was engaged in an armed conflict with al Qaeda and the Taliban, President Bush had to answer a series of important questions. First, what rules applied in a non-traditional war against a non-state actor? Would the Geneva Conventions apply to our conflict with al Qaeda? ${ }^{44}$ Would they apply to our conflict with the Taliban? The answers to these questions would form the foundation for future decisions regarding detention and potential trials.

At the outset, President Bush directed that our government explore all options within the law to protect Americans. ${ }^{45}$ In order to meet the President's directive, Administration officials first had to determine the extent of our domestic and international legal obligations. ${ }^{46}$ The Geneva Conventions, the four 1949 treaties ratified by the United States, provide the basic framework between signatory countries regarding the treatment of combat detainees. ${ }^{47}$ After discussions with Administration lawyers, I raised the question of the application of the Geneva Conventions to our war against al Qaeda and the

\footnotetext{
44. See LATHAM \& LATHAM, supra note 24 , at 27-31.

45. See Yoo, supra note 21 , at 34-36.

46. See id.

47. See LATHAM \& LATHAM, supra note 24 , at 27-28.
} 
Taliban for the first time with the President towards the end of October 2001. I informed him that his decision would govern our legal obligations on detention and interrogation. The decision would affect world public opinion about the United States. I also advised him that there was good faith disagreement on the law and on the appropriate policy for the United States. As he had done on other occasions, the President told me in no uncertain terms to give him the law; he was elected to decide the policy. For President Bush, three main principles would guide his decision regarding the status and treatment of detainees. $^{48}$

First, his decision had to be consistent with the United States' domestic and international legal obligations. ${ }^{49} \mathrm{He}$ understood these were difficult legal issues. He was aware that bright lawyers could disagree-and did in this case- over the legality of certain options as well as the scope of his presidential authority under the Constitution. ${ }^{50} \mathrm{He}$ expected the lawyers to exercise their best judgment and act in good faith without personal bias when advising him of the limits of our legal obligations.

Second, President Bush understood that winning the war on terrorism required the United States to win the war of information. ${ }^{51}$ Our government had to gather as much information as legally permissible about the motivation and capabilities of our enemy and about future plots. ${ }^{52}$ The best source of that information were those captured by the United States and coalition forces; however, many Administration officials believed we were less likely to obtain information from an individual who was advised of his Miranda rights to remain silent, represented by counsel, and placed in our criminal justice system. ${ }^{53}$ Similarly, the Geneva Conventions protect prisoners of war from any form of coercion-positive or negative- to secure information of any kind from the informant. ${ }^{54}$ In a fight against a non-state actor waging an unconventional war in violation of the laws of war, this was unacceptable to the Commander in Chief. The President wanted the flexibility under the law to gather the information necessary to protect the national security of the United States.

Third, President Bush understood that, in addition to meeting our legal obligations, the United States had to adhere to certain acceptable standards of

48. See infra notes 49-56 and accompanying text.

49. See Yoo, supra note 21 , at 34-36.

50. See id. (comparing the opinion of military lawyers of the Pentagon, known as "JAGs," with the Justice Department's opinion).

51. See GolDSMITH, supra note 42, at 71-74 (discussing the multitude of information of possible threats to the United States and the difficulty of dealing with that information).

52. See id. (describing the compiling of the threat matrix).

53. See Memorandum of Jay S. Bybee, Assistant Attorney Gen. to William J. Haynes II, Dep't of Def.: Office of Gen. Counsel on the Potential Legal Constraints Applicable to Interrogations of Persons Captured by U.S. Armed Forces in Afghanistan (Feb. 26, 2002), available at http://www.justice.gov/olc/docs/memoconstraints-feb2002.pdf.

54. Geneva Convention Relative to the Treatment of Prisoners of War, art. 17, Aug. 12, 1949, 6 U.S.T. 3316, 75 U.N.T.S. 135 [hereinafter Geneva Convention POWs]. 
conduct towards detainees. ${ }^{55}$ The United States has always been and remains one of the most ardent supporters of the protections under the Geneva Conventions. ${ }^{56}$ I believe he appreciated that our country had to continue to set the example relative to humane treatment as defined by our laws.

By its terms, the Geneva Conventions are international agreements between "High Contracting Parties," in other words, between nation-states. ${ }^{57}$ OLC informed White House lawyers, and thus the President, that the Geneva Conventions did not apply as a matter of law to the United States' fight with al Qaeda because al Qaeda was not a nation-state and had not signed the Conventions. ${ }^{58}$ Some organizations and international groups condemned this legal advice, arguing that the Geneva Conventions were intended to apply, or at least should apply, to every armed conflict. ${ }^{59}$ That may be a worthy goal; however, that would be a question of policy for the nation's policymakers to decide- and that is not what the treaties say. As a lawyer, I was quite comfortable with the legal advice of the Justice Department. The signatories to a treaty must be able to rely on the plain meaning of the words of the treaty. ${ }^{60}$

But even if the Conventions did apply to our conflict with al Qaeda, OLC informed us that al Qaeda did not qualify for prisoner of war protections under the treaties because its members were not lawful combatants. ${ }^{61}$ According to Article 4(2) of the Geneva Convention Relative to the Treatment of Prisoners of War, one fighting not as a member of the armed forces to a country by definition cannot be a person who is a prisoner of war unless the organized resistance is: one that is commanded by a person responsible for his subordinates; one "having a fixed distinctive sign recognizable at a distance"; one that carries arms openly; and one that conducts its "operations in accordance with the laws and customs of war." ${ }^{, 62}$ OLC concluded that because of al Qaeda's undisputed attacks on innocent civilians and their practice of disguising themselves as civilians while waging war, members of al Qaeda were not entitled to prisoner of war protections as a matter of law. ${ }^{63}$

55. See also Memorandum of John Yoo, Deputy Assistant Attorney Gen. and Robert J. Delahunty, Special Counsel, U.S. Dep't of Justice to William J. Haynes II, Gen. Counsel, Dep't of Def. on Application of Treaties and Laws to al Qaeda and Taliban Detainees (Jan. 9, 2002), available at http://www.gwu.edw nsarchiv/NSAEBB/NSAEBB127/02.01.09.pdf (discussing the international implications of suspending the Geneva Conventions with regard to Afghanistan).

56. See Yoo, supra note 21 , at 44 .

57. Third Geneva Convention: General Provisions art. 2, Aug. 12, 1949, 6 U.S.T. 3316, 75 U.N.T.S. 135 [hereinafter Third Geneva Convention].

58. See YoO, supra note 21, at 33-34.

59. See id. at 34-36.

60. See id. at 212-14.

61. See id. at 34-36.

62. Geneva Convention POWs, supra note 54, at art. 4(2).

63. See Memorandum from Jay S. Bybee, Assistant Attorney Gen., to Alberto R. Gonzales, Counsel to the President, and William J. Haynes II, Gen. Counsel of the Dep't of Def. on the Application of Treaties and Laws to al Qaeda and Taliban Detainees (Jan. 22, 2002), available at http://www.justice.gov/olc/docs/memolaws-taliban-detainees.pdf [hereinafter Gonzales and Haynes]. 
Lawyers with the Justice Department found that America's conflict with the Taliban raised different issues. ${ }^{64}$ For instance, the Taliban arguably operated as the de facto government of Afghanistan, and Afghanistan was a party to the Geneva Conventions. ${ }^{65}$ OLC, however, suggested that the President, as Commander in Chief and Chief Executive, could suspend the Geneva Conventions upon his determination that the sovereign state of Afghanistan ceased to exist. ${ }^{66}$ The Department cited various examples in which a territory lost an effective government and essentially failed. ${ }^{67}$ If the President declined to make this finding, OLC informed us the President could, if he chose to, still deny Taliban members the protection given to prisoners of war because Taliban members did not meet Convention requirements under Article 4(2) ${ }^{68}$ Like al Qaeda, members of the Taliban did not operate under responsible military command, wear distinctive insignia, or obey the laws of war. ${ }^{69}$

The Geneva Conventions provide that if there is any doubt as to a detainee's status, the detainee shall enjoy the protections of the Conventions until a competent tribunal determines the detainee's status. ${ }^{70}$ In practice, a competent tribunal customarily included a relatively quick battlefield determination by two or more field officers. ${ }^{71}$ The Justice Department, however, believed the President's power to interpret treaties authorized him to declare that members of the Taliban, as a group, did not meet the Geneva requirements under Article $4(2){ }^{72}$ I agreed that, as a legal matter, the individual members of the Taliban had forfeited their rights to prisoner of war protections. I deferred to OLC on the failed state theory and the President's authority to decide whether members of the Taliban as a group were or were not entitled to prisoner of war protections.

On January 18, 2002, President Bush informed me that, based on the legal advice from OLC, he determined that the United States would take the position that the Geneva Conventions did not apply with respect to the conflict with al Qaeda or to the conflict with the Taliban. Almost immediately, however, even before his position was known publicly, the President agreed to reconsider primarily upon the urging of the Secretary of State. ${ }^{73}$ Some officials at the State Department apparently believed that the Geneva Conventions applied to both conflicts as a matter of policy and law. ${ }^{74}$ The State Department believed it

64. See id. at 105 .

65. See id. at 95-102.

66. See id.

67. See id. at 105 .

68. See id. at 110.

69. See Third Geneva Convention, supra note 57, at art. 4(A)(1)-(3); Gonzales and Haynes, supra note 63 , at 110 .

70. Third Geneva Convention, supra note 57, at art. 5.

71. See YoO, supra note 21 , at 29.

72. See Gonzales and Haynes, supra note 63 , at 110.

73. See Memorandum from the Dep't of State to White House Counsel Advising that the Geneva Conventions Should Apply (Feb. 2, 2002).

74. See id. 
important for the United States to declare publicly that the Conventions applied to these conflicts. ${ }^{75}$

Over the next two weeks, passionate, but respectful, arguments were made both in support of and in opposition to the President's January 18, 2002 position. The Justice Department issued a written opinion on January 22, 2002, formalizing the informal advice they had previously given. ${ }^{76}$ One principal member on the National Security Council (NSC) declared the United States should take a leadership role in the treatment of detainees. ${ }^{77}$ Another principal expressed concern about affording rights to terrorists who were not legally entitled to them. ${ }^{78}$ One principal argued that this new kind of war against an unconventional enemy argued for a new paradigm in the treatment of detainees. ${ }^{79}$ Yet another took the position that domestic law concerns regarding criminal prosecutions could be substantially alleviated by the President's January 18, 2002 decision. ${ }^{80}$ Finally, others believed domestic law concerns should not be a factor in determining the United States' international legal obligations. ${ }^{81}$

As the discussions continued, views sometimes shifted. For example, the State Department initially took the position that the Geneva Conventions applied to our conflict with al Qaeda and the Taliban as a matter of law and policy. ${ }^{82}$ Later, that position softened, and the State Department agreed with OLC that as a matter of law, the Geneva Conventions did not apply to the U.S. conflict with al Qaeda because al Qaeda was not a "High Contracting Party.",33 Consequently, al Qaeda was not entitled to prisoner of war protections. ${ }^{84}$ The State Department, however, disagreed with the Justice Department's "failed state" theory regarding Afghanistan. ${ }^{85}$ In part, the State Department argued that if the Geneva Conventions could be suspended because Afghanistan had become a failed state, then all of its treaties and international obligations could also be suspended. ${ }^{86}$ This uncertainty of its legal obligations would significantly disrupt Afghanistan's economy and terminate its contractual

75. See id.

76. See Gonzales and Haynes, supra note 63 , at 81 .

77. See id.

78. See id.

79. See id.

80. See id.

81. See id.

82. See Memorandum from Colin L. Powell, U.S. Sec'y of State, to Alberto R. Gonzales, Counsel to the President on the Applicability of the Geneva Convention to the Conflict in Afghanistan (Jan. 26, 2002), available at http://www.gwu.edu/ nsarchiv/NSAEBB/NSAEBB127/02.01 .26.pdf [hereinafter Powell].

83. Memorandum of William H. Taft, IV, Legal Advisor to the U.S. Dep't of State, to Alberto R. Gonzales, Counsel to the President on Comments on the Counsel to the President's Paper on the Geneva Convention (Feb. 2, 2002), available at http://www.gwu.edw/nsarchiv/NSAEBB/NSAEBB 127/02.02.02\% 20DOS\%20Geneva.pdf [hereinafter Taft].

84. Id.

85. Id.

86. See id. 
relationships with third parties. ${ }^{87}$ Therefore, the State Department did not concur with the Justice Department that Taliban members were not entitled to prisoner of war protections as a legal matter. ${ }^{88}$

Furthermore, the State Department argued that the United States should afford the Taliban members prisoner of war protections as a matter of policy. ${ }^{89}$ Not doing so, they argued, would damage U.S. standing in the world and would undermine the standards of treatment for captured American soldiers. ${ }^{90}$ The State Department also expressed concern that denying prisoner of war status could undermine the U.S. military culture, which emphasizes maintaining the highest standards of conduct in combat, and could, accordingly, introduce an element of uncertainty in the status of adversaries. ${ }^{91}$

Some senior officials at the Department of Defense shared similar concerns. They argued that the Geneva Conventions were fully binding obligations of the United States under customary international law. They further argued that the United States had always applied the Geneva Conventions to other conflicts. It was, they claimed, part of our custom. It did not matter that al Qaeda had not signed the Conventions. I did not agree. It seemed plain to me and to the OLC lawyers studying the issue that it was not part of U.S. custom to provide additional rights to unlawful combatants. To the contrary, the U.S. government had already expressly rejected such a view, because in 1977 additional protocols to the Conventions extended prisoner of war protections to fighters of non-state actors. ${ }^{92}$ President Ronald Reagan, however, did not pursue Senate ratification because he believed terrorists who do not obey the laws of war should not be given the same rights as those who do. ${ }^{93}$

The military Joint Chiefs of Staff were understandably concerned with the effect that this decision and the subsequent U.S. treatment of these detainees would have upon the treatment of captured U.S. military personnel abroad. The United States had more troops stationed worldwide than any other country, and, therefore, had more at risk with this decision. ${ }^{94}$ The Chairman and Vice Chairman of the Joint Chiefs warned that there had to be absolute clarity regarding the rules of engagement when so many of our soldiers were eighteen and nineteen year-old kids operating under highly stressful situations. They argued the moral case for the application of the Geneva Conventions, and they

\footnotetext{
87. See id.

88. Id.

89. Id.

90. Id.

91. Powell, supra note 82.

92. See YoO, supra note 21, at 25.

93. Id.

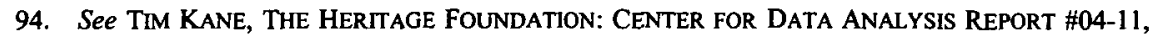
GLOBAL U.S. TROOP DEPLOYMENT, 1950-2003 (2004), http://www.heritage.org/research/nationalsecurity/cda
} 04-11.cfm. 
gave assurances that the military could successfully wage the war against al Qaeda and the Taliban subject to the requirements of the Geneva Conventions.

On February 1, 2002, the Attorney General submitted a letter to the President advising him that if he determined that the Geneva Conventions did not apply to our conflict with al Qaeda and the Taliban,

various legal risks of liability, litigation, and criminal prosecution are minimized .... [A] Presidential determination against treaty applicability would provide the highest assurance that no court would subsequently entertain charges that American military officers, intelligence officials, or law enforcement officials violated Geneva Convention rules relating to field conduct, detention conduct or interrogation of detainees. The War Crimes Act of 1996 makes violation of parts of the Geneva Convention a crime in the United States. ${ }^{95}$

The President focused considerable attention on this matter. He read various memos, articles, and the letter from the Attorney General. ${ }^{96} \mathrm{He}$ heard directly the competing views both privately and during group discussions. On February 7, 2002, President Bush communicated his decision in a two-page memo to the Vice President, Secretary of State, Secretary of Defense, Attorney General, Chief of Staff to the President, Director of Central Intelligence, Assistant to the President for National Security Affairs, and Chairman of the Joint Chiefs of Staff. ${ }^{97}$ Pursuant to his authority as Commander in Chief and Chief Executive of the United States, and relying on the legal opinion of the Department of Justice dated January 22, 2002, and on the letter opinion of the Attorney General in his letter of February 1, 2002, President Bush made several determinations.

One, he accepted the legal conclusions of the Justice Department and determined that none of the provisions of Geneva applied to our conflict with al Qaeda because, among other reasons, al Qaeda was not a "High Contracting Party" to the Geneva Conventions. ${ }^{98}$

Two, the President accepted the legal conclusion of the Attorney General and the Department of Justice that he had constitutional authority to suspend the Geneva Conventions between the United States and Afghanistan, but he declined to exercise that authority. ${ }^{99}$ He determined that the provisions of Geneva would apply to the United States' present conflict with the Taliban. ${ }^{100}$

95. Letter from John Ashcroft, Attomey Gen., to George W. Bush, President of the United States (Feb. 1, 2002), available at http://www.gwu.edu/ nsarchiv/NSAEBB/NSAEBB 127/020201.pdf.

96. Id.

97. Memorandum from George W. Bush, President of the United States, to the Vice President, the Sec'y of State, the Sec'y of Def., the Attorney Gen., Chief of Staff to the President, Director of Central Intelligence, Assistant to the President for Nat'l Security Affairs, Chairman of the Joint Chiefs of Staff (Feb. 7, 2002), available at http://www.gwu.edu/nsarchiv/NSAEBB/NSAEBB127/02.02.07.pdf.

98. Id.

99. Id.

100. Id. 
Three, the President accepted the legal conclusions of the Justice Department and determined that Common Article 3 of the Geneva Conventions "does not apply to either al Qaeda or Taliban detainees, because, among other reasons, the relevant conflicts are international in scope and common Article 3 apples only to 'armed conflict not of an international character.", 101

Four, "[b]ased on the facts supplied by the Department of Defense" as well as the Justice Department's recommendation, President Bush determined "that the Taliban detainees [were] unlawful combatants and, therefore, [did] not qualify as prisoners of war under Article 4" of the Geneva Conventions. ${ }^{102}$ Also, because Geneva did not apply to the conflict with al Qaeda, al Qaeda detainees did not qualify as prisoners of war. ${ }^{103}$

Recognizing the importance of reaffirming our support of the Geneva Conventions, the President went on to say that "[o]ur Nation has been and will continue to be a strong supporter of Geneva and its principles." ${ }^{104}$ Further, he declared that "[a]s a matter of policy, the United States Armed Forces [would] continue to treat detainees humanely and, to the extent appropriate and consistent with military necessity, in a manner consistent with the principles of Geneva." 05

Finally, acknowledging the legitimate concerns of the Joint Chiefs regarding the potential future mistreatment of U.S. military personnel, President Bush declared that the "United States [would] hold states, organizations, and individuals who gain control of United States personnel responsible for treating such personnel humanely and consistent with applicable law."106 Unlike al Qaeda and the Taliban, as a matter of international law, our soldiers would be entitled to full prisoner of war protections because our soldiers are trained to fight according to the laws of war: wear uniforms with insignia, operate under a unified command structure, and carry arms openly. ${ }^{107}$ Citing previous examples, some of the NSC principals had argued that treating the captured humanely, like prisoners of war, would encourage more humane treatment for captured American soldiers. There were equally passionate advocates who believed that our treatment of al Qaeda and Taliban detainees would matter little to this enemy. Al Qaeda and the Taliban mistreated innocent civilians before President Bush's determination, and some of the NSC principals believed they would continue to mistreat civilians and captured coalition soldiers no matter what the President decided. ${ }^{108}$

\footnotetext{
101. Id.

102. Id.

103. Id.

104. Id.

105. Id.

106. Id.

107. See Yoo, supra note 21 , at 26.

108. See Philippe Migaux, Al Qaeda, in THE History OF TERrorism 322-25 (Gérard Chaliand \& Amaud Blin eds., 2007).
} 
The ramifications of the President's order were significant. Accordingly, U.S. personnel could continue to gather information and lawfully ask detainees for more than name, rank, social security number, and date of birth. ${ }^{109}$ The President ordered humane treatment, but U.S. personnel would not have to grant such privileges as scientific instruments, athletic uniforms, and commissary privileges, which the Geneva Convention requires nations to provide to prisoners of war. ${ }^{110}$ Instead, U.S. personnel could offer such privileges as an inducement for information. ${ }^{111}$

The President's determination regarding Common Article 3 proved important because it prohibits, among other things, "outrages upon personal dignity, in particular humiliating and degrading treatment."112 This prohibition's meaning is uncertain and contested. European courts have given analogous language an extraordinary and burdensome reading. ${ }^{113}$ Indeed, in some cases, European courts have read similar language as a license to micromanage prison conditions and severely limit the interrogation of terrorists. ${ }^{114}$ Because the Supreme Court has noted that, in interpreting a treaty, judicial decisions rendered by international tribunals deserve "respectful consideration," foreign decisions might significantly affect the ability of our government to gather information. ${ }^{115}$ For example, interpretations by the European Court of Human Rights of the language "degrading treatment" or punishment might require the United States to treat captured al Qaeda terrorists better than U.S. domestic criminals. ${ }^{116}$ The European Court of Human Rights deemed the following conduct degrading: (1) for a government to fail to recognize a legal change in gender after a sex change operation; (2) for a government to hold someone on death row for many years with knowledge that at some point they will be executed; (3) for a government to force two inmates sharing a cell to use an open toilet in that cell; (4) for a government not to provide a toilet in the cell when confining someone to a cell overnight; and (5) for a government to imprison someone in a cell without windows with exposure to outside light. ${ }^{117}$

I believe in the rule of law, in the Geneva Conventions, and in the Conventions' basic protections for captured lawful combatants and the civilian population in a time of war. I have been accused of describing the Geneva Conventions as quaint. Not true. What I wrote in a leaked draft memorandum

109. See Yoo, supra note 21 , at $39-40$.

110. Id. at 40.

111. Id.

112. Geneva Convention for the Amelioration of the Condition of the Wounded and Sick in Armed Forces in the Field, art. 3(1)(c), Aug. 12, 1949, 6 U.S.T. 3316, 175 U.N.T.S. 135.

113. See X v. F.R.G., App. No. 6694/74, 11 Eur. Comm'n H.R. Dec. \& Rep. 16 (1977).

114. See Soering v. United Kingdom, 161 Eur. Ct. H.R. (ser. A) (1989).

115. Breard v. Greene, 523 U.S. 371, 375 (1998).

116. Geneva Convention for the Amelioration of the Condition of the Wounded and Sick in Armed Forces in the Field, supra note 112, at art. 3.

117. See, e.g., X v. F.R.G., App. No. 6694/74, 11 Eur. Comm'n H.R. Dec. \& Rep. 16 (1977). 
to the President in January 2002 was that "[i]n my judgment, this new paradigm renders obsolete Geneva's strict limitations on questioning of enemy prisoners and renders quaint some of its provisions requiring that captured enemies be afforded such things as commissary privileges, scrip (i.e., advances of monthly pay), athletic uniforms, and scientific instruments." privileges are quaint apparently is shared by the British House of Commons Foreign Affairs Committee, who recommended in 2007 that the British government recognize that "the Geneva Conventions are failing to provide necessary protection because they lack clarity and are out of date."119 Furthermore, the President's decision that unlawful enemy combatants would not have rights under the Geneva Conventions was codified into law by Congress as official U.S. policy in $\S 5$ of the Military Commissions Act, which prohibits a person from invoking the Geneva Conventions in any habeas corpus or other civil action as assurance of rights in any court of the United States or its states or territories.

The President's decision established a new legal paradigm for the United States for dealing with non-state actors fighting an unconventional war using tactics in violation of the laws of war. This new legal framework places a priority on gathering information over prosecution, but honors America's traditional respect for human dignity as reflected in our laws. By publicly declaring that the United States is in a war against al Qaeda, by embracing the law of war framework that allows a country to detain enemy combatants without charges, and by declaring that the United States will try certain terrorists in military commissions for violations of the laws of war, the Obama Administration has embraced this paradigm as correct and essential to protecting the national security interests of the United States.

II.

Immediately following the beginning of hostilities in Afghanistan, the United States began capturing enemy combatants on the battlefield. At first, detainees were held in makeshift facilities in the war zone-facilities that quickly became inadequate as the number of detainees swelled beyond capacity. ${ }^{120}$ The U.S. government had to decide what to do with the captured combatants. ${ }^{121}$ Government officials clearly understood our moral and legal obligation not to kill these captives. ${ }^{122}$ As a matter of military necessity, the

118. Memorandum from Alberto R. Gonzales, Counsel to the President, to George W. Bush, President of the United States (Jan. 25, 2002), available at http://www.gwu.edu/ nsarchiv/NSAEBB/NSAEBB 127/02.01.25.pdf.

119. FOREIGN AFFAIRS COMMITTEE, VISIT TO GUANTANAMO BAY, 2006-7, H.C. 44, at 27 (emphasis added).

120. See KaREN GREENBERG, THE LEAST WORST PlaCE: GuANTANAMo's FIRST 100 DaYS 1 (2009).

121. See id.

122. See id. 
government decided to detain captured combatants so they could not rejoin the battle against the United States and her allies. ${ }^{123}$ But where?

The Pentagon had the lead, but various agencies were also involved in developing the appropriate policy regarding long-term detention. ${ }^{124}$ I worked with a team of Administration lawyers to advise the policy makers, including the President, of the legal implications of various policy options. The government briefly explored the notion of attempting to return captured combatants to their home countries. This was considered unworkable for many of the detainees and inconsistent with the national security interests of our country. Most of the captives were from Afghanistan, and there was no government to speak of at the time that we trusted would continue to detain these combatants and keep them from rejoining the fight against the United States.

Government officials also considered detaining captured combatants in either a new or existing detention facility in Afghanistan. ${ }^{125}$ This plan, however, was considered too dangerous for the detainees and for the American soldiers guarding them in a war zone. ${ }^{126}$

Because we had an obligation to consider all options, there was limited discussion about detaining captured combatants on military bases in the United States. But we had immediate concerns about security and few, if any, of us believed that the American people would tolerate their government bringing terrorists into the homeland just a few months after a terrorist attack on our country. This option was rejected almost immediately. Administration lawyers also had serious questions about the legal ramifications of bringing alien combatants into the United States. ${ }^{127}$ These foreign terrorists would arguably be entitled to certain constitutional and statutory rights that they would not be entitled to if detained outside the United States. No one welcomed the idea of foreign killers targeting government officials with civil actions in our courts and further burdening our court system with additional claims.

The feasibility of using a naval vessel as a floating detention facility was briefly considered, but quickly rejected. ${ }^{128}$ Finally, the government looked at the naval station at Guantanamo Bay, Cuba. ${ }^{129}$ The site was remote and secure. ${ }^{130}$ Access could be controlled and there was no surrounding civilian population that would be placed at risk. ${ }^{131}$ The government could virtually

\footnotetext{
123. See id. at $4-6$.

124. See id.

125. See id. at 4.

126. See id.

127. See id. at 5 .

128. See id. at 4-5.

129. See id. at 6.

130. See id.

131. See id. at 10-14.
} 
guarantee the safety of the detainees as well as the safety of those guarding them. ${ }^{132}$

Justice Department lawyers were asked whether combatants captured on the battlefield of Afghanistan and detained at Guantanamo would be entitled to habeas corpus rights in our federal courts. ${ }^{133}$ Since the beginning of the Republic, the United States has never recognized the rights of aliens, captured in battle against the U.S., to challenge their detention outside the United States in our courts-in other words, the right to file a habeas petition. ${ }^{134}$ For instance, Confederate soldiers detained in this country during the Civil War were not afforded such rights. ${ }^{135}$ Also, the United States brought hundreds of thousands of captured soldiers to the United States during World War II, but no alien combatant was afforded the right to challenge their detention. ${ }^{136}$ The controlling case on point appeared to be the World War II-era case of Johnson $v$. Eisentrager. ${ }^{137}$ Eisentrager involved habeas proceedings for twenty-one German nationals who were captured and charged with violating the laws of war by collecting and reporting intelligence regarding the movement of American armed forces to the Japanese armed forces. ${ }^{138}$ Following the surrender of Japan, the U.S. Army captured the German nationals in Japan. ${ }^{139}$ The German nationals were tried and convicted by a U.S. military commission in China for violating the laws of war by engaging in, permitting, or ordering continued military activity against the United States after the surrender of Germany and before the surrender of Japan. ${ }^{140}$

The Supreme Court held that these German nationals did not have standing to sue for writ of habeas corpus. ${ }^{141}$ The Court noted that "[w]e are cited to no instance where a court, in this or any other country where the writ is known, has issued it on behalf of an alien enemy who, at no relevant time and in no stage of his captivity, has been within its territorial jurisdiction." "142 The Court continued, saying that in order to grant the writ, it "must hold that a prisoner of our military authorities is constitutionally entitled to the writ, even though he (a) is an enemy alien; (b) has never been or resided in the United States; (c) was captured outside of our territory and there held in military

132. See id.

133. See Memorandum from Patrick F. Philbin, Deputy Assistant Attorney Gen. and John C. Yo, Deputy Assistant Attomey Gen., to William J. Haynes, Gen. Counsel for the Dep't of Def. (Dec. 28, 2001), available at http://www.gwu.edu/ nsarchiv/NSAEBB/NSAEBB127/01.12.28.pdf [hereinafter Philbin, Yoo, \& Haynes].

134. See Johnson v. Eisentrager, 339 U.S. 763, 776-77 (1950).

135. DAVID M. SILVER, LINCOLN'S SUPREME COURT 28 (1957).

136. Arnold P. Krammer, The Handbook of Texas Online, http://www.tshaonline.org/handbook/online/ articles/GG/qugl.html.

137. See Eisentrager, 339 U.S. at 765-66.

138. Id.

139. Id. at 766 .

140. Id.

141. Id. at 776 .

142. Id. at 768 . 
custody as a prisoner of war; (d) was tried and convicted by a Military Commission sitting outside the United States; (e) for offenses against laws of war committed outside the United States; $(f)$ and is at all times imprisoned outside the United States." ${ }^{143}$ The Court refused to do so. ${ }^{144}$

Based primarily on this precedent and the facts the lawyers understood would be common to each of the detainees at Guantanamo, OLC informed the Department of Defense and the White House that they believed a federal court probably could not entertain an application for a writ of habeas corpus by an alien detained at Guantanamo. ${ }^{145}$ The opinion acknowledged, however, the possibility a district court would entertain such an application. ${ }^{146}$ Based in large part upon the preference of senior officials at the Department of Defense, in late December 2001, a consensus emerged within the Bush Administration to use the Guantanamo Naval Station as a detention facility. ${ }^{147}$ The President did not select the site, although he was kept apprised throughout the process and informed of the final decision and the reasons supporting it. ${ }^{148}$ Contrary to at least one source, the lawyers did not make this decision. ${ }^{149}$

From my perspective, Guantanamo Bay was selected as a detention facility because it represented the best among a short list of imperfect choices. It was not selected based on a belief that the United States could operate there beyond U.S. law or without limitations under international law. This decision was made before the President's decision regarding the application of the Geneva Conventions to our conflict with al Qaeda and the Taliban. ${ }^{150}$ So, at least in my mind at the time, the application of the Geneva Conventions to our treatment of Guantanamo detainees was an open question. Even after the President's February 7, 2002 decision that members of al Qaeda and the Taliban were not entitled to prisoner of war protections, I believed, at a minimum, our conduct arguably remained subject to our legal obligations under our domestic antitorture statute ${ }^{151}$ and the Convention Against Torture. ${ }^{152}$ In my judgment, security concerns drove this decision, and Guantanamo would likely have been

143. Id. at 777 .

144. Id. at 778.

145. YoO, supra note 21 , at 142.

146. See Philbin, Yoo, \& Haynes, supra note 133, at 29.

147. See GREENBERG, supra note 120 , at 20.

148. See generally id. at 1-22 (describing the Guantanamo Bay selection process).

149. See JANE MAYER, THE DARK SidE: THE INSIDE STORY OF HOW THE WAR ON TERROR TURNED INTO A WAR ON AMERICAN IDEALS 147 (2008) ("The White House lawyers had picked the location because of its unique legal status.").

150. See id. at 123.

151. 18 U.S.C. $\$ \$ 2340-2340$ B (2006).

152. United Nations Convention Against Torture and Other Cruel, Inhuman or Degrading Treatment or Punishment, Dec. 10, 1984, 1465 U.N.T.S. 85, available at http://www2.ohchr.org/english/law/cat.htm. 
selected as the detention facility even if OLC had opined from the beginning that Guantanamo detainees had habeas rights. ${ }^{153}$

III.

There is much disagreement at the time of this writing about the merits of trying a terrorist in a criminal court in the United States. ${ }^{154}$ As the nation's former chief law enforcement officer, I can assure you that, based on historical precedent, the Justice Department is capable of successfully prosecuting some terrorism cases depending on the circumstances. For example, Timothy McVeigh, Terry Nichols, Theodore Kaczynski, Ramzi Yousef, and Omar Abdel-Rahman, the so-called "Blind Sheik," were all tried in our federal courts and found guilty of terrorism-related acts. ${ }^{155}$ These trials, however, occurred prior to the September 11, 2001 terrorist attacks. ${ }^{156}$ At the time these cases were tried, the conventional mindset was that acts of terrorism were a criminal matter to be adjudicated within our criminal justice system along with crimes committed by bank robbers, car thieves, and drug dealers.

After September 11, 2001, that mindset changed and the government adopted a new strategy. The strategy included a menu of options for the United States. Depending on the circumstances, members of the Bush Administration envisioned some terrorists would be brought to justice in the criminal justice system, while others would be subject to trial by military commissions or detained indefinitely under the laws of armed conflict. The United States would transfer others to their home country for further detention or release.

Initially, I assumed that the President would decide the ultimate disposition of suspected terrorists. Administration lawyers believed that a presidential determination under the President's constitutional authority as Commander in Chief would be given greater deference by the courts than if the Attorney General or the Secretary of Defense made the decision. In addition, some in the Administration believed that this was the type of decision that the American people would expect the President to make. President Bush, however, quickly determined that this decision should not be made at the White House, but instead should be made by civilian and military prosecutors. Accordingly, in the fall of 2001 , we began a formal interagency process to develop a decision matrix for the disposition of captured terrorists. A

153. The torture opinions were issued in August 2002, which was after the President's February 7, 2002 decision regarding POW protections not being granted to al Qaeda and Taliban members. Suggestions by critics that Guantanamo was selected so the President could act outside of the torture statutes are false.

154. See generally YoO, supra note 21 , at 204-30 (discussing the disagreements about whether to try terrorists in a criminal court or a military commission).

155. United States v. Yousef, 327 F.3d 56, 170-73 (2d Cir. 2003); United States v. Kaczynski, 239 F.3d 1108, 1119 (9th Cir. 2001); United States v. Nichols, 169 F.3d 1255, 1280 (10th Cir. 1999); United States v. Rahman, 189 F.3d 88, 160 (2d Cir. 1999); United States v. McVeigh, 153 F.3d 1166, 1222 (10th Cir. 1998).

156. Yousef, 327 F.3d at 170-73; Kaczynski, 239 F.3d at 1119; Nichols, 169 F.3d at 1280; Rahman, 189 F.3d at 160; McVeigh, 153 F.3d at 1222. 
formalized process would address all possible contingencies and it would ensure a more consistent and more dependable decision by the Administration. This would protect the President from criticism about haphazard justice. The goal in 2001 was to finalize the decision matrix and have the Attorney General and the Secretary of Defense announce the process the following year.

Decisions regarding disposition were driven by the new legal paradigm of first gathering intelligence information, then bringing detainees to justice once it could be done without compromising the national security of our country. That paradigm created challenges for our federal prosecutors. The courts in our criminal justice system operate under a set of procedures that require the government to bring criminal charges and timely adjudicate guilt or innocence. ${ }^{157}$ Defendants have a Fourth Amendment right to Miranda warnings, and a Sixth Amendment right to confront witnesses against them and have an attorney present while being questioned. ${ }^{158}$ Defendants have the right to be free from force, coercion and deception, to remain silent when prosecuted for a criminal offense, and to not be forced in any way to provide incriminating evidence. ${ }^{159}$ Also, there are well-established protections pertaining to the admissibility of evidence, such as the exclusionary rule designed to exclude evidence obtained in violation of a criminal defendant's Fourth Amendment rights and the prohibition of hearsay evidence. ${ }^{160}$ These protections are important underpinnings of American justice and make our criminal justice system the best in the world.

Following the September 11, 2001 attacks, government officials recognized the challenge of pursuing a successful criminal prosecution of a high-profile terrorist during an ongoing conflict. ${ }^{161}$ In previous military conflicts, trials for war crimes usually occurred after the conflict was overand for good reasons. For instance, a high-profile trial during ongoing hostilities may divert attention from the war effort. Also, the propaganda generated by the defendant in a public trial may damage morale in the field and back home. Battlefield commanders and front-line soldiers may be called away from duty to answer questions as witnesses. Most damaging, the government might be forced to prove its case by sharing information that would compromise the ongoing war effort.

It is true that John Walker Lindh, Richard Reid, and Zacarias Moussaoui were all suspected terrorists convicted in our criminal courts during the Bush Administration. ${ }^{162}$ A closer examination of the facts surrounding these cases, however, reveals that these prosecutions were far from routine and should not

157. See 18 U.S.C. $\S \S 3161-3174$ (2006) (citing the Speedy Trial Act of 1974).

158. U.S. Const. amends. VI, IV.

159. U.S. CONST. amend. V.

160. See U.S. CONST. amend. IV; FED. R. EVID. 802.

161. See United States v. Moussaoui, 365 F.3d 292, 295-98 (4th Cir. 2004); see also infra text accompanying notes 189-90 (taking nearly five years to bring Moussaoui to justice).

162. See United States v. Reid, 369 F.3d 619, 619-20 (1st Cir. 2004); Moussaoui, 365 F.3d at 295-96; United States v. Lindh, 212 F. Supp. 2d S41, 545 (E.D. Va. 2002). 
automatically be cited in support of future criminal prosecutions for other terrorists. ${ }^{163}$ There are still many unanswered questions about the ability of federal prosecutors to successfully prosecute high-profile terrorists during an ongoing conflict without compromising the national security of our country. From the outset, I did not believe that every person accused of committing an act of terrorism should be tried in our criminal courts. But neither did I believe they should necessarily all be tried in military commissions. For me, the appropriate disposition depended on the circumstances-ultimately, what was best for the United States.

John Walker Lindh was captured by Afghan Northern Alliance forces on the battlefields of Afghanistan in November 2001, fighting with the Taliban against America and the Northern Alliance. ${ }^{164}$ He was injured at the time of capture and detained overseas for some period of time by the Northern Alliance and then the Department of Defense. ${ }^{165}$ Because Walker Lindh is an American citizen, I assumed at the time that he would not be prosecuted in a military commission. Lawyers at the Justice Department concluded quickly that they could successfully prosecute Walker Lindh in our criminal courts. ${ }^{166}$ Because the Depaitment of Defense had initial custody of Walker Lindh, however, Defense Department lawyers spent considerable time examining possible military charges against him. After much deliberation, a consensus emerged among the lawyers at the Defense Department and the Justice Department that the challenges to a military trial weighed in favor of a Justice Department prosecution. On January 16, 2002, the Attorney General announced that Walker Lindh would be prosecuted in a criminal court. ${ }^{167}$ As they often do in major criminal prosecutions, federal prosecutors pursued the most serious charges against Walker Lindh. ${ }^{168}$ In part, this is done to encourage a defendant to plea to lesser charges. On advice of counsel, Walker Lindh pled guilty and, in October 2002, received a twenty-year sentence. ${ }^{169}$

Richard Reid, a British citizen, attempted to detonate plastic explosives hidden in his sneakers on an American Airlines flight from Paris to Miami on December 22, 2001. ${ }^{170}$ Reid called himself a disciple of Osama bin Laden and an enemy of the United States. ${ }^{171}$ At the time of his capture, the Administration had not finalized a formal process to determine whether someone like Reid should be tried in federal court or a military commission, returned to his home

163. See supra note 162.

164. Lindh, 212 F. Supp. $2 d$ at $545-47$.

165. See id.

166. See id. at 547.

167. John Ashcroft, Attorney Gen., Attorney Gen. Transcript (June 15, 2002), available at http://www. justice.gov/archive/ag/speeches/2002/01 1502walkertranscript.htm.

168. See Indictment, United States v. Lindh, Crim No. 02-37A (E.D. Va. 2002), available at hitp:/news. findlaw.com/hdocs/docs/lindh/uswlindh020502cmp.html.

169. See Plea Agreement, United States v. Lindh, 212 F. Supp. 2d 541 (No. 02-37A).

170. United States v. Reid, 369 F.3d 619, 619-20 (1st Cir. 2004).

171. See id. at 620 . 
country, or detained indefinitely for the duration of hostilities. At the time, we were still developing the procedures for military commissions, so at best a military commission represented a long-term option. At the time of the capture, our thinking about interrogations and the importance of gathering intelligence had not yet been fully developed. Finally, at the time of capture we did not have the wisdom gained from experience that we have now about the difficulty of determining who is a valuable intelligence asset and who is a continuing threat to the United States. Reid was arrested by law enforcement, Mirandized, and placed into our criminal justice system from the outset. ${ }^{172}$ Based on his statements and conduct, I was led to believe that Reid had little to no intelligence value. These circumstances all weighed in favor of the status quo. The Justice Department wanted to prosecute Reid, and no one presented a compelling reason not to do so. Because, he claimed, he wanted to spare his family the difficulty of undergoing a lengthy trial, Reid pled guilty to terrorism charges in October 2002, and he was sentenced on January 31, 2003, to life in prison with no possibility of parole. ${ }^{173}$

Zacarias Moussaoui, a French citizen, was arrested in August 2001 in Minnesota after instructors at the flight school he was attending reported suspicious behavior. ${ }^{174}$ Moussaoui was arrested by law enforcement, Mirandized, and indicted in December 2001 for his participation in the conspiracies leading to the September 11 th attacks. ${ }^{175}$ Moussaoui later admitted he was an al Qaeda member, knew of al Qaeda's plot to attack the United States, and had agreed to assist with the plan after bin Laden selected him to fly a plane into the White House. ${ }^{176}$

The Attorney General advocated for Moussaoui to be prosecuted by the Justice Department in our criminal courts. ${ }^{177}$ Although federal prosecutors anticipated Moussaoui would request access to sensitive or classified information and to al Qaeda associates who were within U.S. custody, they were confident they could convict him. ${ }^{178}$ Others within the Bush Administration opposed a criminal trial fearing it would compromise our national security. ${ }^{179}$ Unlike Reid, they argued, Moussaoui intended to be part of the September 11, 2001 attacks; therefore, he should be tried as a war criminal. ${ }^{180}$

172. See id.

173. See id.

174. United States v. Moussaoui, 365 F.3d 292, 295-96 (4th Cir. 2004).

175. See id.

176. Brief of Petitioner-Appellant at 87-89, United States v. Moussaoui, No. 03-4792 (4th Cir. Oct. 31, 2003).

177. See Yoo, supra note 21 , at 210.

178. See infra text accompanying note 184 .

179. See YoO, supra note 21, at 217-18 (stating that if Justice Department officials had to try Moussaoui over again, they would have sent him to a military commission, listing one of their reasons to be the ability to better deal with confidential information).

180. See id. at $210-11$. 
In contrast to Reid, there was considerable discussion within the White House as to whether Moussaoui should be tried in a military commission instead of our criminal courts. I worried about the challenges of a criminal trial, but I also agreed with the Attorney General that we needed to have a post-9/11 terrorism case in federal court to see firsthand whether our criminal justice system could accommodate the prosecution of a high profile terrorist during ongoing hostilities. Ultimately, I recommended that we accept the Justice Department's recommendation to try Moussaoui in criminal court. The President agreed with me over other advisors' concerns, but he reserved the right to change his mind if he believed at any time the trial would compromise our national security. Because the case involved national security issues, the Department of Justice imposed Special Administrative Measures to prevent communications with other terrorists. ${ }^{181}$ The Department also received a protective order granted in accordance with the Classified Information Procedures Act. ${ }^{182}$ Under the protective order, classified government information used in discovery would only be available to those with certain security clearances. ${ }^{183}$

As we predicted, in September 2002, Moussaoui requested access to several al Qaeda associates, all of whom were in U.S. custody and three of whom the district court ordered the Government to produce. ${ }^{184}$ I could feel the "I told you so" chorus from those officials who had argued for a military commission. Fortunately for the United States, the Fourth Circuit Court of Appeals reversed the district court's order, finding that other witnesses were available who could provide Moussaoui with essentially the same defense. ${ }^{185}$

Eventually, Moussaoui pled guilty to all counts on March 29, 2005-three and a half years after his indictment. ${ }^{186}$ Even following his guilty plea, Moussaoui challenged his conviction to the Fourth Circuit asserting, among other things, that the protective order deprived him of access to exculpatory evidence. ${ }^{187}$ The Fourth Circuit ruled against Moussaoui, and he is serving a life sentence. ${ }^{188}$

Although the Moussaoui conviction was a victory for the United States, the case showed us how difficult it could be to successfully prosecute a highprofile terrorist during ongoing hostilities. In essence, Moussaoui represented himself and pled guilty, but the United States still was not able to bring him to justice for four years. ${ }^{189}$ The proceedings consumed enormous time and

181. United States v. Moussaoui, 59l F.3d 263, 267 (4th Cir. 2010).

182. Id.

183. Id.

184. United States v. Moussaoui, 333 F.3d 509, 513 (4th Cir. 2003).

185. United States v. Moussaoui, 382 F.3d 453, 482 (4th Cir. 2004).

186. Moussaoui, 591 F.3d at 271.

187. Id. at 279.

188. Id. at 307.

189. See id. at 266-72 (encompassing Moussaoui's indictment in December 2001 to his guilty pleas in April 2005). 
resources of the Justice Department, and Department lawyers did not have to battle against a high-powered legal team. ${ }^{190}$ Even with almost four years of trial and appellate court rulings in this case, there are still many unanswered questions about acceptable substitutions of evidence and witnesses. For instance, if in the future an accused terrorist in a criminal trial demands to confront an al Qaeda associate in U.S. custody, the United States will have to either produce him if there are no other witnesses who could provide the defendant with essentially the same defense or else dismiss the charges. ${ }^{191}$ Finally, although overwhelming evidence was presented demonstrating that Moussaoui was trained and intended to participate in the murder of over 3,000 innocent Americans, the United States government was unable to get the death penalty over the objections of a single holdout juror. ${ }^{192}$

At the time of this writing, President Barack Obama is reconsidering his earlier decision to try Khalid Sheikh Mohammed (KSM), the purported architect of the September 11 th attacks, in criminal court in New York City. ${ }^{193}$ Supporters of President Obama's decision accuse critics of applying a double standard. ${ }^{194}$ Walker Lindh, Reid, and Moussaoui, they claim, were brought to justice in our criminal courts without objection from those now criticizing President Obama. ${ }^{195}$ While it is true that the United States elected to prosecute Walker Lindh, Reid, and Moussaoui in our criminal courts, the circumstances in these cases were the deciding factor regarding prosecution-circumstances that are substantially different than those surrounding KSM. ${ }^{196}$

Those supporters who cite the cases of Walker Lindh, Reid, and Moussaoui to justify trying KSM in a criminal trial fundamentally misunderstand that each case must stand alone on its own facts. The fact that the United States was able to successfully prosecute Walker Lindh, Reid, and Moussaoui tells us nothing about whether we should prosecute KSM or any other alleged terrorist in our criminal courts. At most, it tells us that it is possible to do so- and even that is subject to considerable debate depending on the circumstances.

Supporters also cry "foul" over criticism of the Obama Administration for providing Miranda rights to Umar Farouk Abdulmutallab, the "Christmas Day Bomber," who tried to detonate explosives in his underwear aboard a passenger

190. See id. at 267-70 (describing Moussaoui's demands to proceed pro se).

191. See id. at $284,287$.

192. See id. at 302.

193. See KSM Trial: White House "Increasingly Unsure" How to Proceed, Huffington Post, http://www.huffingtonpost.com/2010/02/13/ksm-trial-white-house-inc_n_461650.html.

194. See infra notes $195-96$ and accompanying text.

195. See PETER JAN HONIGSBERG, OUR NATION UNHINGED: THE HUMAN CONSEQUENCES OF THE WAR ON TERROR 197-217 (2009).

196. Compare id. (discussing the successful prosecutions of Walker Lindh, Reid, and Moussaoui in U.S. courts), with MARC A. ThIESSEN, COURTING Disaster, How the CIA KEPT AMERICA SAFE AND How BARACK OBAMA IS INVITING THE NEXT ATTACK $379-83$ (2010) (discussing the danger of trying KSM in a U.S. court). 
jet on December 25, 2009. ${ }^{197}$ Richard Reid, the Shoe Bomber, they point out, was also "Mirandized," and Republicans did not complain then. ${ }^{198}$ Some Republican members of Congress have responded that the Bush Administration made a mistake in electing to prosecute any terrorist in our criminal courts. ${ }^{199}$

These officials apparently believe that the United States failed to learn valuable intelligence because those individuals were given their Miranda rights. ${ }^{200}$ If true, I would have to concede that it may have been a mistake to Mirandize someone like Reid. There is no evidence, however, to support that claim. While we do not know what we do not know, there has been no successful attack against American citizens in this country since September 11, 2001 , and there is no evidence to suggest we were made less safe or failed to gain important intelligence because of the decision to prosecute these three in our criminal courts.

Those who criticize the decision to try Reid in our criminal courts instead of a military commission fail also to appreciate that, in reality, the United States did not have this option because Reid is a British citizen. ${ }^{201}$ After hostilities began in Afghanistan, the United States captured several British citizens fighting against coalition forces. ${ }^{202}$ The British Attorney General expressed concerns to me directly and other Administration lawyers about prosecuting British citizens in U.S. military commissions. Over the course of negotiations lasting several months, lawyers in the Bush Administration discussed various changes to the military commission procedures to accommodate the concerns of the British as to how the British detainees, if prosecuted, could be assured of fair trials that met international standards. ${ }^{203}$ Ultimately, that effort was unsuccessful, and President Bush agreed to the Prime Minister's direct request that the British detainees be transferred to the custody of the British authorities. ${ }^{204}$ Since Reid was also a British citizen, I am quite confident that if the United States had, in 2002, elected to try him in a military commission, the British government would have raised similar objections and requested his transfer to Great Britain. Given the long history of cooperation between the United States and Great Britain, and the deep respect between the President and

197. See Walter Pincus, Christmas Day Bomb Suspect Was Read Miranda Rights Nine Hours Afier Arrest, WASH. POST, Feb. 15, 2010 , at A06.

198. See Steve Benen, Reid Was Mirandized, Too . ..., WASH. MONTHLY, Feb. 2, 2010, available at http://www.washingtonmonthly.com/archives/individual/2010_02/022213.php.

199. See YoO, supra note 21, at 210-20.

200. See Hilary Term, The Why and How of Preventive Detention in the War on Terror, 26 T.M. COOLEY L. REV. 51,60 (2009).

201. See Tung Yin, Enemies of the State: Rational Classification in the War on Terrorism, 11 LEWIS \& ClARK L. REV. 903, 932 (2007).

202. See Peter Bergen, Look Where the Terrorists Are From, N.Y. TMES, July 9, 2005, available at http://www.nytimes.com (search "Look Where Terrorists Are From"; then follow first hyperlink to article).

203. Press Release, U.S. Dep't of Def. (July 23, 2003), available at http://www.globalsecurity.org/ security/library/news/2003/07/sec-030723-dod02.htm.

204. Press Release, U.S. Dep't of Def. (Jan. 25, 2005), available at http:/www.globalsecurity.org/ security/library/news/2005/01/sec-050125-dod01.htm. 
the Prime Minister, I feel confident that such a request would have been honored. Therefore, Reid would only be brought to justice in one of two ways: either in Great Britain or in the American criminal justice system.

There was no similar diplomatic pressure to place Moussaoui in our criminal justice system. I understand why some people question whether it was a mistake to do so. ${ }^{205}$ His prosecution was expensive and time consuming. ${ }^{206}$ Furthermore, he used the prosecution as a platform to denounce America and promote al Qaeda. ${ }^{207}$ But at the outset we knew that would be the case and we were willing to pay that cost in order to gain a better understanding of the challenges of trying a high profile terrorist in our criminal courts during our ongoing conflict against al Qaeda. In the end, Moussaoui-like Walker Lindh and Reid - was brought to justice and, based on what I observed as Counsel to the President, then as Attorney General, and based on what I know today, the national security of our country was not compromised. No one has presented any evidence that any of these men had actionable intelligence that the United States did not obtain because they were in our criminal justice system rather than a military commission.

Based on what I know, I do not support the decision to bring KSM into the United States to stand trial in our criminal justice system. ${ }^{208} \mathrm{~A}$ criminal trial in a federal courthouse will pose significant logistical and security challenges. KSM and his high powered legal team will place the United States on trial and use the venue as an opportunity to promote al Qaeda. ${ }^{209}$ Because he was not detained initially by law enforcement, KSM will challenge the admissibility of evidence collected early by his captors. Some evidence may have been lost or destroyed in the war zone. KSM will also try to have evidence excluded on the grounds that it was obtained through torture or enhanced techniques in violation of his constitutional rights. He will try to gain access to classified information that he claims will prove his innocence. He will argue that detainees of Guantanamo can prove his innocence. So, he will demand these detainees be brought into the United States so he can confront them as he is entitled to under the Sixth Amendment of our Constitution. Once in the United States, KSM will bring civil actions against current and former government officials for violations of his constitutional and statutory rights. Why should the United States give him this platform?

The rule of law does not require that KSM be tried in a criminal court. The rule of law would be better served in this case with a military trial at the appropriate time under procedures approved by Congress. Quickly after September 11, 2001, President Bush realized the disadvantage of having a President too involved in making decisions about prosecutions. But these

205. See Yoo, supra note 21, at 210-13.

206. See id.

207. See id. at 211.

208. See THIESSEN, supra note 196 , at $378-80$.

209. See id. 
decisions should not be left in the hands of one cabinet official. Multiple agencies have equities in the disposition of individuals like KSM. For the sake of our civilian population and the intelligence agents and analysts who have risked their lives and careers in defense of our country, these decisions should be based upon the collective wisdom of the senior prosecutors at Justice and Defense as well as the views of the Director of National Intelligence and senior intelligence officials at the Central Intelligence Agency.

IV.

Anticipating the challenges of successfully prosecuting terrorists in our criminal courts during ongoing hostilities, I began working with lawyers on another option for the President in the fall of 2001. Military commissions have been used extensively in previous conflicts, including the Spanish-American War, the Civil War, and the Revolutionary War, to prosecute enemy combatants for war crimes. ${ }^{210}$ In addition, the United States used a military commission during World War II to try Nazi saboteurs captured in the United States who had plans to sabotage east coast factories and facilities. ${ }^{211}$ President Franklin Delano Roosevelt issued orders creating a military commission, defining its jurisdiction, establishing governing procedures, and ordering that the saboteurs be given a full and fair trial. ${ }^{212}$ In Ex Parte Quirin, the Supreme Court upheld President Roosevelt's use of military commissions. ${ }^{213}$

After studying this history and consulting with OLC, I concluded in the fall of 2001 that the President should be given the opportunity to consider whether he wanted the option of military commissions to bring terrorists to justice. I envisioned the United States using military commissions for special cases such as bin Laden and other top al Qaeda leaders. During the final weeks of October 2001, I first discussed the topic of military commissions with the President. I explained the Roosevelt precedent with the Nazi saboteurs and the Supreme Court decision in Ex parte Quirin upholding President Roosevelt's military commission. ${ }^{214}$ The President concluded it was a strong move. Shortly after that, the President and I spoke again about the possible use of commissions. He told me he wanted military commissions as a tool, but he was concerned about trying American citizens in a military commission. I returned to my desk and continued to work quietly with the lawyers to develop a military commissions option.

In the beginning of November, President Bush instructed the Attorney General and me to begin drafting up the necessary paperwork to lay the

210. A Brief History of Military Commissions, TME, May 18, 2009, at 14, available at http:/www.time. com/time/nation/article/0,8599,1899131,00.html.

211. See Ex Parte Quirin, 317 U.S. 1, 21-22 (1942).

212. See Proclamation No. 2561, 7 Fed. Reg. 5, 101 (July 2, 1942).

213. Ex Parte Quirin, 317 U.S. at 2.

214. See id. 
foundation for military commissions. He wanted it on his desk as quickly as possible. The work intensified. It involved the lawyers in the Department of Justice, Department of Defense, the Counsel's Office, and the Vice President's Office. There has been some suggestion the Attorney General did not favor military commissions. ${ }^{215}$ I never asked him, but the suggestion surprises me. From my observation, the Attorney General understood the United States had to utilize the assets of law enforcement, the military, and the intelligence community to defeat al Qaeda. He himself raised the possibility of using military commissions directly with the President in a meeting in early November 2001. The Attorney General was a forceful advocate for a strong Executive Branch and a staunch defender of the Department of Justice as an institution. He argued, rightfully, for the Justice Department to play an appropriate and meaningful role in the development of military commissions and in decisions regarding their use. The commissions would still be a military function in accordance with the wishes of the Secretary of Defense, but the courts and the public would likely be reassured, the Attorney General argued, if the Justice Department had a role. He was right. The Justice Department would have to defend the military commissions process from legal challenges in our courts. On November 17, 2001, President Bush issued a Military Order called the Detention, Treatment, and Trial of Certain Non-Citizens in the War Against Terrorism. ${ }^{216}$ The order was patterned after the order used by President Roosevelt and upheld by the Supreme Court. ${ }^{217}$

Based on my review of precedent and on OLC's legal judgment, I believed the military commissions were not only consistent with the rule of law, but also under the right circumstances would allow the United States to bring our enemy to justice without compromising our national security. But opposition from civil liberties groups and defense lawyers emerged immediately. ${ }^{218}$ Critics claimed that the commissions were fundamentally unfair, that they denied detainees basic due process, and that the procedures all but guaranteed a conviction for the government. ${ }^{219}$ They argued military commissions were not consistent with the rule of law, that the FDR approach had been superseded by subsequent law, such as the Geneva Conventions and the Uniform Code of Military Justice. ${ }^{220}$ Although the commissions included protections not afforded to the accused in military courts-martial, even some

215. See Yoo, supra note 21 , at 210-11.

216. Military Order of Nov. 13, 2001-Detention, Treatment, and Trial of Certain Non-Citizens in the War Against Terrorism, 66 Fed. Reg. 57, 833 (Nov. 16, 2001).

217. See Ex Parte Quirin, 317 U.S. at 2; Proclamation No. 2561, 7 Fed. Reg. 5101 (July 7, 1942).

218. See YoO, supra note 21, at 205; Neal K. Katyal \& Laurence H. Tribe, Waging War, Deciding Guilt: Trying the Military Tribunals, 111 YALE L.J. 1259, 1309 (2002); Editorial, A Travesty of Justice, N.Y. TIMES, Nov. 16, 2001, at A24.

219. HONIGSBERG, supra note 195 , at 114.

220. See YOO, supra note 21, at 205, 209, 229; see also Editorial, supra note 218 (arguing that military commissions would erode the rule of law). 
military lawyers were critical of the military commissions. ${ }^{221}$ Challenges to the procedures arose in our courts and from members of Congress. ${ }^{222}$ There was criticism in the press and concern from our allies. ${ }^{223}$ It was only a matter of time, as discussed below, before the Supreme Court became vested with this issue. $^{224}$

The Executive Branch responded to these concerns by, over time, clarifying the procedures and providing additional rights and protections to detainees. ${ }^{225}$ Congress also attempted to place military commissions on firmer legal footing. ${ }^{226}$ First, Congress passed in 2006 the Military Commissions Act, which was followed by the Military Commissions Act of 2009. ${ }^{227}$

Congress intended these changes in procedures to give detainees additional rights and protections. ${ }^{228}$ For example, now they have greater access to information and are able to more effectively limit the government's use of information. ${ }^{229}$ Detainees are in a much stronger position now to confront witnesses. ${ }^{230}$ Despite these changes and the statutory support of Congress, legal challenges have continued to tie up the commissions in our federal courts. ${ }^{231}$ From time to time, a frustrated President Bush would ask me if we would ever have a military commission trial. He did not want to hear excuses about legal challenges; he wanted these terrorists to be held accountable. For me, our inability to stand up military commissions as an accepted, if not routine, method of bringing terrorists to justice is one of the disappointments of my tenure in office.

V.

Like virtually every other wartime president who took extraordinary measures to protect our country, several of President Bush's decisions were challenged in our courts. ${ }^{232}$ Since September 11, 2001, there have been a number of terrorism-related federal court cases, including four major cases

221. See YoO, supra note 21 , at 209.

222. See id. at 206-09.

223. See Editorial, supra note 218; Dan Eggen, Ashcrofi Defends Anti-Terrorism Steps; Civil Liberties Groups' Attacks 'Only Aid Terrorists,' Senate Panel Told, WASH. POST, Dec. 7, 2001, at Al.

224. See infra notes 232-66 and accompanying text.

225. See THIESSEN, supra note 196, at 42-44.

226. See infra note 227 and accompanying text.

227. See Military Commissions Act of 2006, Pub. L. No. 109-366, 120 Stat. 2600 (codified as amended in scattered sections of 10 U.S.C.); Military Commissions Act of 2009, Pub. L. No. 111-84, 123 Stat. 2190 (2009).

228. See infra notes 229-31 and accompanying text.

229. See YoO, supra note 21 , at $217-20$.

230. See id. at 217-30.

231. See id. at 230.

232. See Boumediene v. Bush, 128 S. Ct. 2229 (2008); Hamdan v. Rumsfeld, 548 U.S. 557 (2006); Hamdi v. Rumsfeld, 542 U.S. 507 (2004); Rasul v. Bush, 542 U.S. 466 (2004). 
decided by the Supreme Court: Hamdi v. Rumsfeld, Rasul v. Bush, Hamdan v. Rumsfeld, and Boumedeine v. Bush. ${ }^{233}$

Hamdi v. Rumsfeld involved a challenge to President Bush's deter, ination that Yaser Esam Hamdi was an enemy combatant. ${ }^{234}$ Although an American citizen, Hamdi was captured bearing arms and fighting against American forces on the battlefields of Afghanistan. ${ }^{235}$ President Bush designated Hamdi as an enemy combatant based upon the findings and recommendations of senior officials, including those at the Department of Defense and the Central Intelligence Agency. ${ }^{236}$ A unanimous panel on the Fourth Circuit Court of Appeals agreed with the Government:

[B]ecause it is undisputed that Hamdi was captured in a zone of active combat in a foreign theater of conflict, we hold that the submitted declaration is a sufficient basis upon which to conclude that the Commander in Chief has constitutionally detained Hamdi pursuant to the war powers entrusted to him by the United States Constitution. No further factual inquiry is necessary or proper.... 237

The case was appealed to the Supreme Court. ${ }^{238}$ There, the Government argued that the court of appeals correctly found that Hamdi was an enemy combatant because Hamdi's detention fell squarely within the President's constitutional powers and is bolstered by, and by no means contrary to, the actions of Congress. ${ }^{239}$ Furthermore, the Government argued that the President's classification of an individual as an enemy combatant is entitled to a court's utmost deference and that attempts at further factual development regarding "the military's enemy-combatant determination would present formidable constitutional and practical difficulties." 240

In 2004, a divided Supreme Court issued four opinions and vacated the Fourth Circuit decision, holding that due process required that a U.S. citizen being held as an enemy combatant had to be given meaningful opportunity to contest the factual basis of his detention. ${ }^{241}$ Citing Justice O'Connor's words that "a state of war is not a blank check for the President," this case is often held up by Bush critics as an example of gross overreaching by the President in fighting terrorism. ${ }^{242}$

233. See Boumediene, 128 S. Ct. at 2229; Hamdan, 548 U.S. at 557; Hamdi, 542 U.S. at 507; Rasul, 542 U.S. at 466 ; Hamdan, 548 U.S. at 557.

234. See Hamdi, 542 U.S. at 507.

235. See id. at 510 .

236. See id. at 510-11.

237. Hamdi v. Rumsfeld, 316 F.3d 450, 459 (4th Cir. 2003), vacated, 542 U.S. 507, 514 (2004).

238. Hamdi, 542 U.S. at 509.

239. See Brief for the Respondents at 9, Hamdi v. Rumsfeld, 542 U.S. 507, No. 03-6696 (2004).

240. See id. at 11 .

241. Hamdi, 542 U.S. at 509.

242. See id. at 536. 
Often overlooked, however, are the portions of the decision helpful to the government's efforts to fight terrorism. ${ }^{243}$ First, although the Court rejected the power of the Commander in Chief alone to designate enemy combatants, a clear majority of the Justices agreed that a court's review of the Executive's actions should be deferential. ${ }^{244}$ Equally important, Justice O'Connor and a majority of the Court recognized the legitimate application of the laws of armed conflict. ${ }^{245}$ Justice O'Connor confirmed that the President could detain an enemy combatant without charges for the duration of the hostilities, even if the enemy combatant is an American citizen. ${ }^{246}$ The authority to hold enemy combatants extends to those who are U.S. citizens. As the Court said, "[ $[$ ] here is no bar to this Nation's holding one of its own citizens as an enemy combatant.,"247

The Supreme Court also recognized that Congress has authorized the detention of enemy combatants through the AUMF and that preventing an enemy combatant's return to the battlefield is "a fundamental incident of waging war."248 Although the Supreme Court recognized that American citizens held as enemy combatants must be given notice of the basis for their detention and an opportunity to rebut the allegations, and thus rejected the more limited procedures used by the government, the Court clearly rejected Hamdi's contention, which the district court adopted, that the government should afford him process similar to that which accompanies a criminal trial.

In fashioning appropriate procedures, the Court acknowledged the weighty governmental interests in "ensuring that those who have in fact fought with the enemy during a war do not return to battle against the United States" and in avoiding distraction of military personnel from the war effort. ${ }^{249}$ The Court accordingly insisted only on the "core elements" of notice and an opportunity to be heard but recognized that "enemy-combatant proceedings may be tailored to alleviate their uncommon potential to burden the Executive at a time of ongoing military conflict." 250 Among the examples of possible "tailoring" suggested by the Court were use of hearsay and a presumption in favor of the government's evidence. The Court also recognized that the standards it articulated could be satisfied by an appropriately authorized and properly constituted military tribunal, and that a court faced with a habeas petition after such a tribunal would only need to assure that the tribunal had followed minimum requirements of due process. Accordingly, on July 7, 2004, the Deputy Defense Secretary issued an order to the Secretary of the Navy instituting a set of new procedures called the Combatant Status Review Tribunals to meet the

\footnotetext{
243. See infra notes 244-51 and accompanying text.

244. See Hamdi, 542 U.S. at 536-37.

245. See id. at 519-20.

246. See id. at 519.

247. See id.

248. Id.

249. Id. at 531.

250. Id. at 533 .
} 
Court's requirements of notice of the basis for detention and an opportunity to rebut the allegations for accused enemy combatants.

An important, but often overlooked, point about the Hamdi decision is that it concerned an American citizen. ${ }^{251}$ Justice O'Connor's oft-cited phrase mentioned above is, unfortunately, usually abbreviated. ${ }^{252}$ The full quote is that "a state of war is not a blank check for the President when it comes to the rights of the Nation's citizens." ${ }^{253}$ Importantly, this case was about the rights of American citizens, not the rights of foreign terrorists. Assuming that American citizens have greater rights than non-citizens under our Constitution, lawyers in the Bush Administration read Hamdi as logically standing for the proposition that the government is entitled to even greater deference when dealing with alien enemy combatants on issues of habeas. ${ }^{254}$

Rasul v. Bush involved an attempt by Shafiq Rasul, a detainee at Guantanamo Bay, Cuba, to challenge his detention in federal court through a habeas corpus proceeding. ${ }^{255}$ Rasul, a non-U.S. citizen, was captured overseas. ${ }^{256}$ A unanimous panel of the District of Columbia Circuit held for the Government, holding that the privilege of litigation did not extend to aliens in a military custody outside of U.S. territory. ${ }^{257}$

The case was appealed to the Supreme Court. ${ }^{258}$ There, the Government argued that under Johnson v. Eisentrager, U.S. courts lacked jurisdiction over Guantanamo detainees, for Eisentrager "makes clear that sovereignty, not mere control, is the touchstone of its jurisdictional rule."259

On the day the Supreme Court handed down its decision in Hamdi, a divided court issued three opinions reversing the D.C. Circuit. ${ }^{260}$ The Supreme Court held that the federal habeas statute conferred jurisdiction on the district court to hear challenges by aliens held at Guantanamo Bay. ${ }^{261}$ The Court in Johnson $v$. Eisentrager had previously rejected the claim that nonresident aliens held overseas by the United States had habeas rights in our federal courts. ${ }^{262}$ But this Court dealt with the fifty-year-old Eisentrager precedent by finding that the United States exercised complete dominion over the U.S. base at

251. See id. at 536 .

252. See, e.g., Michael Stokes Paulsen, The War Power, 33 HARV. J.L. \& PUB. Pol'y 113, 125 (2010); David E. Pozen, Deep Secrecy, 62 STAN. L. REV. 257, 322 (2010); Dawinder S. Sidhu, Wartime America and the Wire: A Response to Posner's Post-9/1/ Constitutional Framework, 20 GEO. MASON U. CIV. RTS. L.J.37, 60 (2009).

253. See Hamdi, 542 U.S. at 536 (emphasis added).

254. See Robert M. Chesney, National Security Fact Deference, 95 VA. L. REV. 1361, 1366-71 (2009).

255. Rasul v. Bush, 542 U.S. 466, 471 (2004).

256. Id. at $470-71$ \& n.l.

257. See id. at $\mathbf{4 7 2 - 7 3 .}$

258. Id. at 473 .

259. Brief of Respondents at 14, Rasul v. Bush, 542 U.S. 466, Nos. 03-334, 03-343 (2004).

260. See Rasul, 542 U.S. at 468 (referring to the majority opinion by Justice Stevens, the concurring opinion by Justice Kennedy, and the dissenting opinion by Justice Scalia).

261. Id. at 480 .

262. See id. at 478-79. 
Guantanamo Bay under an "evergreen" lease with Cuba. ${ }^{263}$ Thus, in the eyes of a majority of the Justices, the base was, in essence, a territory of the United States. ${ }^{264}$

Members of the Castro government in Cuba were probably puzzled to learn that unelected judges had declared a portion of their Caribbean island a territory of the United States, in spite of language in the agreement between the two countries that the leased property remained the sovereign territory of Cuba. ${ }^{265}$ It surprised Bush Administration lawyers to see the Court in Rasul, for the first time, extend habeas rights to aliens detained outside U.S. territory who had never had a presence in the United States. ${ }^{266}$ As we feared, habeas petitions from Guantanamo detainees immediately flooded our federal district courts. ${ }^{267}$ Unfortunately, in hearing these cases, district court judges did what they were accustomed to doing when hearing habeas challenges; they required that the government give alien enemy combatants held outside the United States the same due process entitled to American citizens residing in this country. ${ }^{268}$

What made this particularly frustrating for government lawyers was that Rasul was handed down on the very day a majority in Hamdi made clear that the constitutional requirements of due process for an American enemy combatant were far more limited than district court judges appeared to now be requiring in habeas proceedings involving aliens. ${ }^{269}$ In response to this confusion and the increased caseload in our federal courts, Congress passed the Detainee Treatment Act of 2005 (DTA) in December 2005. ${ }^{270}$ The DTA: (1) prohibits inhumane treatment of prisoners, including those at Guantanamo Bay; (2) requires military interrogations to be performed according to the United States Army Field Manual for Human Intelligence Collector Operations; (3) strips federal courts of jurisdiction to consider habeas corpus filed by prisoners in Guantanamo or other claims asserted by Guantanamo detainees against the U.S. government; and (4) limits appellate review of decisions of the Combatant Status Review Tribunals and Military Commissions. ${ }^{271}$ Congress did not explicitly codify military commissions or otherwise ratify the military commission framework of the Bush Administration. We believed, however,

263. See id. at 480 .

264. See id.

265. See Joseph Lazar, "Cession in Lease" of the Guantanamo Bay Naval Station and Cuba's "Ultimate Sovereignty," 63 AM. J. INT'L L. 116, 116-18 (1969).

266. See HONIGSBERG, supra note 195, at 91-93.

267. See id. at 93 .

268. See Rasul, 542 U.S. at $478-79$

269. Compare Hamdi v. Rumsfeld, 542 U.S. 507, 529-35 (2004) (limiting due process requirements regarding enemy combatants), with Rasul, 542 U.S. at $478-79$ (broadening due process protections for enemy combatants). See also HONIGSBERG, supra note 195, at 92-93 (discussing the response of the lawyers of the Guantanamo detainees to Hamdi and Rasul).

270. STEVEN T. WAX, KAFKA COMES TO AMERICA: FIGHTING FOR JUSTICE IN THE WAR ON TERROR $172-80$ (2008).

271. Id. at 180-81; see Arsalan M. Suleman, Recent Development: Detainee Treatment Act of 2005, 19 HARV. HUM. RTS. J. 257, 259-60 (2006). 
that Congress implicitly approved of the military commissions established by the Bush Administration when it limited the DTA appellate review of the decisions of military commissions. Congress and the President intended that foreign aliens at Guantanamo, who never had a physical presence in the United States, would not have access to our federal courts to challenge their detention. ${ }^{272}$

If the Executive and Legislative branches intended to send a message, the Supreme Court apparently did not want to hear it. ${ }^{273}$ The case of Hamdan $v$. Rumsfeld presented the following questions: (1) whether the rights protected by the Geneva Conventions can be enforced in federal court through habeas corpus petitions and (2) whether the military commission established to try Salim Ahmed Hamdan and others for alleged war crimes were consistent with law. ${ }^{274}$ In another unanimous decision by the District of Columbia Circuit, the court of appeals held (1) the separation of powers doctrine was not violated by the President's designation of a military commission to try an enemy combatant alleged to have fought for al Qaeda; (2) the Geneva Conventions did not give enemy combatants rights to enforce its provisions in court; and (3) even if the Geneva Conventions could be enforced in court, the trial of an enemy combatant by a military commission did not violate his rights under the Conventions. ${ }^{275}$

At this time, I was serving as the Attorney General of the United States, and the Department of Justice was responsible for defending the Detainee Treatment Act. The case was appealed to the Supreme Court. ${ }^{276}$ The Government argued that the President had authority to convene the military commission against Hamdan, and furthermore, that Congress recognized the President's authority to do so through the DTA. ${ }^{277}$ In 2006, a bitterly divided Supreme Court issued six opinions, reversing the D.C. Circuit. ${ }^{278}$ The Court held that (1) the DTA did not cut off existing habeas suits by Guantanamo detainees; (2) Common Article 3 of the Geneva Conventions applied to the U.S. conflict with al Qaeda; and (3) military commission procedures were unlawful because the structure and procedure both violate the Uniform Code of Military Justice. ${ }^{279}$ The Court held that the Executive Branch lacked the constitutional authority to set up military commissions to try captives taken in the war on terror. ${ }^{280}$ This authority, it said, lies with Congress. ${ }^{281}$

272. See Johnson v. Eisentrager, 339 U.S. 763, $777-78$ (1950); Timothy Endicott, Habeas Corpus and Guantánamo Bay: A View From Abroad, 54 AM. J. JURIS. 1, $2-4$ (2009).

273. See infra notes $274-79$ and accompanying text.

274. See Hamdan v. Rumsfeld, 548 U.S. 557, 567 (2006).

275. Hamdan v. Rumsfeld, 415 F.3d 33, 38-43 (D.C. Cir. 2005), rev'd, 548 U.S. 557 (2006).

276. See Hamdan, 548 U.S. at 567.

277. See id. at $\mathbf{5 5 8 - 5 9 .}$

278. See supra note 275.

279. See Hamdan, 548 U.S. at 558-63.

280. See id. at $559-60$.

281. See id. at 591-92. 
I spoke with a number of public officials in the Executive Branch and Congress about the Court's decision. We had all understood that the DTA would cut off all habeas litigation by Guantanamo detainees. ${ }^{282}$ The Court did not agree. ${ }^{283}$

My staff informed me that the Court's pronouncement on Common Article 3 surprised even some top military lawyers. By its terms, Article 3 applies "[i]n the case of armed conflict not of an international character occurring in the territory of one of the High Contracting Parties." 284 As discussed above, pursuant to his authority as Commander in Chief and Chief Executive of the United States, and exercising his authority to interpret treaties, President Bush expressly declared on February 7, 2002, that "[C]ommon Article 3 of Geneva does not apply to either al Qaeda or Taliban detainees, because, among other reasons, the relevant conflicts are international in scope and [C]ommon Article 3 applies only to 'armed conflict not of an international character." $285 \mathrm{I}$, and many others I spoke with (in and outside the government), could not reconcile the Court's conclusion and the plain language of the Geneva Conventions. ${ }^{286} \mathrm{It}$ certainly appeared to me and many other senior officials in the elected branches of government that the conflict between coalition forces and al Qaeda and the Taliban was a conflict of an international nature. ${ }^{287}$

Congress and the President responded to the Court's decision with the passage of the Military Commissions Act (MCA) in October 2006. ${ }^{288}$ The MCA's stated purpose was "[t]o authorize trial by military commission for violations of the law of war." ${ }^{289}$ The MCA adopted procedures for military commissions. ${ }^{290}$ Anticipating the mischief that judges might create by trying to define "outrages upon personal dignity," the law also made clear that the President of the United States would determine the government's obligations under Common Article 3 of the Geneva Conventions. ${ }^{291}$

No doubt encouraged by the Supreme Court's demonstrated willingness to second guess the President and Congress during a time of war, Lakhdar

282. See id. at $572-74$.

283. See id. at 575-76.

284. Convention (I) for the Amelioration of the Condition of the Wounded and Sick in Armed Forces in the Field, Geneva, art. 3, Aug. 12, 1949, available at http://www.icrc.org/ihl.nsf/WebPrint/365-FULL?Open Document.

285. See source cited supra note 97.

286. See Jonathan F. Mitchell, Legislating Clear-Statement Regimes in National-Security Law, 43 GA. L. REV. 1059, $1093-96$ (2009).

287. See, e.g., Joan Fitzpatrick, Jurisdiction of Military Commissions and the Ambiguous War on Terrorism, 96 AM. J. INT'L L. 345, 348-50 (2002).

288. See Military Commissions Act of 2006, Pub. L. No. 109-366, 120 Stat. 2600 (codified as amended in scattered sections of 10 U.S.C.); The Rt. Hon the Lord Phillips of Worth Matravers, Impact of Terrorism on the Rule of Law, 43 INT'L LAW 13, 21-22 (2009).

289. Military Commissions Act of 2006, supra note 288.

290. See id.

291. See id.; see also Geneva Convention POWs, supra note 54, at art. 3. 
Boumediene, a detainee at Guantanamo, challenged the MCA in our courts. ${ }^{292}$ For the fourth time in four major terrorism cases, a federal appellate panel agreed with the Government. ${ }^{293}$ The D.C. Circuit held that the amendment to habeas corpus statutes precluded jurisdiction over habeas petitions filed by aliens detained as enemy combatants at Guantanamo that were pending on the date of the enactment of the amendment. ${ }^{294}$ The panel also held that the MCA, depriving courts of jurisdiction over habeas petitions of aliens detained as enemy combatants at Guantanamo, does not violate the Suspension Clause of the Constitution. ${ }^{295}$ For the first time in the four major terrorism cases, the panel decision at the court of appeals was not unanimous. ${ }^{296}$

Boumediene appealed to the Supreme Court. ${ }^{297}$ There, the Government argued that the district court did not have jurisdiction over Boumediene's habeas corpus petition under the MCA and that the Suspension Clause did not entitle Boumediene, an alien held outside the sovereign territory of the United States, to any rights. ${ }^{298}$ Additionally, the Government argued that Boumediene's detention was lawful under the AUMF. ${ }^{299}$

In June 2008, a divided Supreme Court in Boumediene v. Bush issued four opinions and again reversed the D.C. Circuit. ${ }^{300}$ The Court held that the Constitution entitled aliens at Guantanamo to habeas corpus to challenge the legality of their detention and that the MCA provision cutting off such challenges effectuated an unconstitutional suspension of the writ of habeas corpus. ${ }^{301}$

Some conservative legal scholars believe that the Supreme Court should resolve only those issues necessary to decide the case or controversy before them. ${ }^{302}$ Others believe that in certain circumstances it is also appropriate for the Court to make broad pronouncements of law to guide the country. ${ }^{303} \mathrm{~A}$ well-known example is the famous desegregation case of Brown v. Board of Education. ${ }^{304}$ Chief Justice Earl Warren reportedly worked hard over a period of months to get a unanimous opinion of the Court on an important issue of law

292. See Boumediene v. Bush, 476 F.3d 981, 987 (D.C. Cir. 2007), cert. granted, 127 S. Ct. 3078 (2007).

293. See id. at $986-87$.

294. See id. at 985-87.

295. See id.

296. See id.

297. See Boumediene v. Bush, 128 S. Ct. 2229, 2229 (2008).

298. See id. at 2244.

299. See id.

300. See id.

301. See id.

302. See, e.g., Barry Friedman, The Importance of Being Positive: The Nature and Function of Judicial Review, 72 U. CIN. L. REV. 1257 n.47 (2004).

303. See id. at 1258-59.

304. See generally Brown v. Bd. of Educ., 349 U.S. 294, 756-57 (1955) (holding that racial discrimination within public education is unconstitutional and that courts of equity may take into account the public interest in eliminating said discrimination). 
that affected the very fabric of our society. ${ }^{305} \mathrm{~A}$ unanimous opinion gives clear guidance to the American people and leaves no question that the law is not going to change with the next vacancy on the Court. ${ }^{306}$

In contrast to the Brown decision, the four terrorism cases produced seventeen opinions, not one of which was able to attract more than five votes. ${ }^{307}$ Lawyers within the Bush Administration anticipated members of the Court would struggle over some of these issues, but we had no idea there would be such disagreement. For example, in the Hamdan case, six of the eight Justices deciding the case felt compelled to write opinions. ${ }^{308}$ Furthermore, those who criticize the government for taking legal positions totally unsupported in the text and history of the law, or who claim that Administration lawyers were pressured to give advice the clients wanted to hear, must explain why eleven of the twelve appellate judges who voted on these four cases at the courts of appeals ruled with the government. ${ }^{309}$ These were difficult questions of law. Critics should ask the members of the Supreme Court whether the answers in these cases were so obvious.

Other legal scholars have criticized the Bush Administration for being too quick to "go-it-alone" in developing and executing anti-terrorism policy. ${ }^{310}$ Pointing to other cases in which the Supreme Court has deferred to the combined political will of the elected branches of government during a time of crisis, such scholars argue that the Bush Administration would have been better off waiting for Congress to provide supporting legislation. ${ }^{311}$ As I have testified before Congress, the American people are best served during a time of crisis when the elected branches of government work together. ${ }^{312}$ I agree that there are several examples in which the Court has respected the President's reliance on his constitutional authority because his actions were buttressed by congressional action. ${ }^{313}$ As we see from the Hamdan and Boumediene cases, however, the Court does not always defer to the elected branches of government working together-even in a time of war. ${ }^{314}$ I would also argue that the Bush Administration did have congressional support. ${ }^{315}$ In passing the AUMF, Congress granted the President broad authority to deal with those

305. See Randall T. Shepard, The Changing Nature of Judicial Leadership, 42 IND. L. REV. 767, 767-68 (2009).

306. See id. at 768.

307. See supra notes 211-17 and accompanying text.

308. See supra note 278 and accompanying text.

309. See supra note 233 and accompanying text.

310. See, e.g., GOLDSMITH, supra note 42, at 123 (2007).

311. See, e.g., Yoo, supra note 21, at viii, 119, 126-27.

312. See Hearing on Justice Dep't Oversight Before the Comm. on S. Judiciary, 2006 WL 2007190 (2006) (statement of Alberto Gonzales, Attorney Gen., Dep't of Justice).

313. See, e.g., Weiner v. United States, 357 U.S. 349, 353-56 (1958); Youngstown Sheet \& Tube Co. v. Sawyer, 343 U.S. 579, 585 (1952); Humphrey's Ex'r v. United States, 295 U.S. 602, 625-26 (1935).

314. See supra notes $211-17$ and accompanying text.

315. See infra notes $316-19$ and accompanying text. 
responsible for the September 11 th attacks. ${ }^{316}$ Justice O'Connor wrote in Hamdi v. Rumsfeld that the AUMF authorized those activities fundamentally incident to waging war. ${ }^{317}$ She wrote that it was of "no moment" that specific actions were not explicitly described in the AUMF. ${ }^{318}$ Congress had authorized those actions fundamentally incident to waging war, including in that case the detention of American citizens who were found to be enemy combatants. ${ }^{319}$

In addition, key members of Congress were briefed on all authorized terrorism-related policies that I was aware of. In some cases, the full intelligence committees were informed in accordance with routine reporting requirements. In other highly sensitive cases, the briefings were more limited consistent with custom and practice. For example, the Chair and Ranking Members of the House and Senate Intelligence Committees received periodic briefings over the course of several years about the Bush Administration's efforts to engage in electronic surveillance to collect information about the enemy, including the Terrorist Surveillance Program. ${ }^{320}$ In time, these briefings also included the Senate Majority Leader and Senate Minority Leader, the Speaker, the House Majority Leader, and the House Minority Leader. In short, the Bush Administration did not go it alone in trying to protect our country.

It is easy for the President to ask for legislation, but it is hard for Congress to quickly pass such legislation giving him additional powers. ${ }^{321}$ Admittedly, the PATRIOT Act, which gave the Executive Branch additional authority to collect and share information necessary for our national security, was passed in a matter of weeks. ${ }^{322}$ But such legislation was passed as the World Trade Center towers lay toppled in flames. ${ }^{323}$ Since its passage, liberals and civil libertarians have demonized the law as a gross violation of the Constitution. ${ }^{324}$ Some members of Congress now claim they were pressured to grant the President these additional powers in the aftermath of the September 11th

316. See supra notes $288-91$ and accompanying text.

317. See Hamdi v. Rumsfeld, 542 U.S. 507, 517 (2004).

318. See id. at 519.

319. See id. at 516-19.

320. The Terrorist Surveillance Program was confirmed by the President of the United States in December 2005. See President's Radio Address to the Nation (broadcast Dec. 17, 2005). Under the program, the National Security Agency was authorized to "intercept the international communications of people with known links to al Qaeda and related terrorist organizations." Press Release, Office of the Press Secretary, President's Radio Address (Dec. 17, 2005), http:/georgewbush-whitehouse.archives.gov/news/ releases/2005/12/20051217.html. Prior to intercepting the communications, however, "the government must have information that establishes a clear link to these terrorist networks." Id.

321. See Abner J. Mikva, Congress: The Purse, the Purpose, and the Power, 21 GA. L. REv. 1, 13-14 (1986).

322. See ARYEH NEIER, LOST LIBERTIES: ASHCROFT AND THE ASSAULT ON PERSONAL FREEDOM, in Civil LIBERTIES vs. NATIONAL SECURITY IN A POST-9/11 WORLD 38 (M. Katherine B. Darmer et al. eds., 2004).

323. See id.

324. See, e.g., Christian Halliburton, Leveling the Playing Field: A New Theory of Exclusion for PostPATRIOT Act America, 70 Mo. L. REV. 519, 557 (2005). 
attacks for fear of appearing unpatriotic and weak on national defense. ${ }^{325}$ The delay and compromise associated with the reauthorization of the PATRIOT Act and with the passage of legislation which modernized the Foreign Intelligence Surveillance Act are far better examples of what happens in the legislative process. ${ }^{326}$

The greatest concern about asking Congress for statutory authority to take offensive and defensive national security measures when you already have constitutional authority, however, is that the enemy may learn about U.S. capabilities and intentions in protecting our country. The legislative process can become politicized. Members understandably wish to openly debate controversial pieces of legislation. This creates the possibility that sensitive sources and methods will be exposed; ongoing operations will be compromised; and our enemies will learn what we as a country are capable of doing to successfully win the war on terror. While I understand special procedural safeguards exist for the passage of national security-related legislation, such measures cannot guarantee that our nation's secrets will not be compromised during the legislative process.

Scholars who suggest that President Bush should have asked for more explicit congressional support, or at least should have asked for it earlier, have the benefit of hindsight as well as the luxury to second-guess. ${ }^{327}$ Decision makers in the arena of public service unfortunately do not receive "do-overs.",328 I concede that there may have been some occasions in which it would have been helpful to have additional congressional support, but at what cost? ${ }^{329} \mathrm{We}$ do not know whether we could have gotten legislation passed in a timely manner, and even if we had, whether the legislative process would have compromised national security operations or sources and methods.

The path chosen by President Bush may have seemed confrontational at times. It may have seemed unilateral and unusually secretive. But it was also successful in protecting our country from another September 11 th-type attack. Respectfully, those who criticize the Bush Administration for stubbornly refusing to go to Congress for legislation were not present at the meetings in the White House when such options were debated. They are unaware of the warnings we received from congressional leaders that pursuing legislation might inform the enemy of our intelligence intentions and capabilities. In the end, it is the President who is personally accountable for the health and welfare of every American like no other political figure. He must decide how best to

325. See JOHN DAVIS, PRESIDENT BUSH AND THE WAR ON TERRORISM: HISTORIC OPPORTUNITY LOST TO COMPLETE HIS FATHER'S LEGACY AND DEFINE HIS OWN PLACE IN HISTORY, in AMERICA'S WAR ON TERROR 108 (Tom Lansford et al., eds. 2009).

326. See U.S. Dep't of Justice, Fact Sheet: USA PATRIOT Act Improvement and Reauthorization Act of 2005 (Mar. 2, 2006), available at http:/www.justice.gov/opa/pr/2006/March/06_opa_113.html.

327. See DAVIS, supra note 325, at 108; GOLDSMITH, supra note 42, at 99-140.

328. See GoLDSMTH, supra note 42 , at 99-140.

329. See id. 
wage this war on terror within the Constitution. He has to safeguard the safety of Americans and our civil liberties under the Constitution.

President George W. Bush's place in history is far from settled. Historians will compare him to previous wartime presidents. In doing so, we will be reminded that President Bush is not the only wartime president to be criticized or accused of abusing power, trampling on the Constitution, and violating the civil liberties of others. ${ }^{330} \mathrm{He}$ is not the first wartime president sued for actions taken in defense of our country. ${ }^{331} \mathrm{He}$ is neither the first president to have his Commander in Chief decisions reviewed by the courts nor the first to have a presidential decision struck down by the courts. ${ }^{332}$ To the contrary, he joins a long and distinguished list. ${ }^{333}$

Generally regarded as one of the greatest American Presidents, Abraham Lincoln appropriated unprecedented powers during the Civil War. ${ }^{334} \mathrm{He}$ used his war powers to blockade Southern ports; to suspend the writ of habeas corpus; to spend money before Congress appropriated it; and to imprison thousands of suspected Confederate sympathizers without trial. ${ }^{335}$ During World War I, Woodrow Wilson ordered the interception of all cable communications between the United States and Europe. ${ }^{336}$ He inferred the authority to do so from the Constitution and from a general congressional authorization to use military force that did not mention anything about surveillance. ${ }^{337} \mathrm{He}$ was widely criticized for his suppression of anti-war movements. ${ }^{338}$ His push to get the United States to join the League of Nations was a public failure that subjected him to ridicule. ${ }^{339}$ Many condemned President Franklin Delano Roosevelt for his economic policies, primarily regulation of the economy, the expansion of the welfare state, and the policy shift from focusing on individual achievement and success to focusing on the collective good. ${ }^{340}$ Critics labeled FDR as a warmonger because, despite the United States' neutrality in the early stages of World War II, his administration

330. See Louis Fisher, Judicial Review of the War Power, 35 PRESIDENTIAL STUD. Q. 466,474 (Sept. 2005); Jules Lobel, The Commander in Chief and the Courts, 37 PRESIDENTIAL STUD. Q. 49, 49 (Mar. 2007); The Honorable Frank J. Williams, Abraham Lincoln and Civil Liberties in Wartime, The Heritage Foundation (May 5, 2004), http://www.heritage.org/research/nationalsecurity/hl834.cfm.

331. See sources cited supra note 330.

332. See id.

333. See id.

334. See id.

335. See id.; GeOfFrey PERRET, LINCOLN's WAR 302 (2004).

336. Prepared Remarks for Attorney Gen. Alberto R. Gonzales at the Georgetown Univ. Law Ctr. (Jan. 24, 2006), http://www.justice.gov/archive/ag/speeches/2006/ag_speech_0601241.html.

337. See id.

338. See THE NEW YORK TIMES: TIMES TOPICS (last updated Feb. 23, 2009), http://topics.nytimes.com/ top/reference/timestopics/people/w/woodrow_wilson/index.html.

339. See id.

340. See Robert Higgs, Regime Uncertainty: Why the Great Depression Lasted So Long and Why Prosperity Resumed After the War, 1 INDEP. REV. 563-64 (1997), available at http://www.independent.org/ pdfftir/tir_01_4_higgs.pdf. 
implemented policies benefiting Great Britain, China, and the Soviet Union. ${ }^{341}$ Critics also characterized President Roosevelt's order authorizing internment of over 100,000 Japanese-Americans, as unconstitutional, racist, and ineffective in stopping Japanese spies. ${ }^{342}$ The media denounced President Harry Truman over such matters as failing to protect our national security in the Cold War in addition to continuing charges of communism and corruption in his Administration. ${ }^{343}$ His decisions placing the United States into the Korean Conflict were routinely challenged and, as discussed below, his seizure of America's steel mills provoked a public rebuke from the Supreme Court. ${ }^{344}$ President Lyndon Johnson was second-guessed repeatedly for his handling of the Vietnam War. ${ }^{345}$ There were dozens of lawsuits filed challenging the President's authority to wage war without a formal declaration or explicit authorization from Congress. ${ }^{346}$

Every wartime American president has had his decisions challenged-and sometimes those challenges were successful. ${ }^{347}$ A strong president will push the elements of his authority under the Constitution and laws of the United States to protect the American people. When he took office, President Bush placed his hand on the Bible and took an oath to preserve, protect, and defend the Constitution of the United States. Even if his actions were unpopular or if the courts say he acted improperly, he acted deliberately and decisively to fulfill his oath and to protect our country in the interest of national security.

VI.

The four terrorism cases decided by the Supreme Court and discussed above, as well as the Moussaoui trial, are instructive on the role of the courts in times of war. ${ }^{348}$ The framers of our Constitution devised a system of checks and balances - the separation of powers-that gave to the executive and legislative branches the authority and responsibility to develop and execute policies necessary to protect America. Courts were expected to exercise judgment as to whether the political branches were acting in accordance with law. Judges do not have the expertise to analyze intelligence reports or execute

341. See GeORge MCJIMSEY, THE PRESIDENCY Of FRANKLIN DELANO RoOSEVELT 185-87 (2000).

342. See GREg ROBINSON, BY ORDER OF THE PRESIDENT: FDR AND THE INTERNMENT OF JAPANESE AMERICANS 108-09, 134, 137, 251 (2001).

343. See FrankLIN D. Mitchell, Harry S. TRUMAN and the NEWS MEDIA: Contentious RELATIONS, BELATED RESPECT 85, 92 (1998).

344. See infra text accompanying notes 375-85.

345. See HERBERT Y. SCHANDLER, THE UNMAKING OF A PRESIDENT: LYNDON JOHNSON AND VIETNAM 194-217 (1977).

346. See Michal R. Belknap, The Warren Court and the Vietnam War: The Limits of Legal Liberalism, 33 GA. L. REV. 65, 101 -11 (1998).

347. See supra notes 334-46 and accompanying text.

348. See Boumediene v. Bush, 553 U.S. 723 (2008); Hamdan v. Rumsfeld, 548 U.S. 557(2006); Hamdi v. Rumsfeld, 542 U.S. 507 (2004); Rasul v. Bush, 542 U.S. 466 (2004); United States v. Moussaoui, 591 F.3d 263 (4th Cir. 2010). 
a battle plan. The complicated and insidious nature of this conflict with a nonstate actor also argues for the courts to give even greater deference to the President and to the Congress as they develop the most effective strategies to protect America.

The historical record of the deference paid by our federal courts to the President's exercise of his war power is decidedly mixed. ${ }^{349}$ There have been extended periods of emergency, such as the Civil War, when the federal courts were quite comfortable in deciding the constitutionality of actions taken by President Abraham Lincoln. ${ }^{350}$ There have been other periods, such as World War II, when the Supreme Court appears to have been very deferential to the elected branches of government. ${ }^{351}$ For example, in Ex Parte Quirin, the Supreme Court upheld the President's use of military commissions. ${ }^{352}$ In United States v. Bethlehem Steel Corp., the Court upheld the government's power to draft the resources of the business community to support the war effort. ${ }^{353}$ In Yakus v. United States, the Court upheld the delegation of price fixing authority of the Price Administrator in the Office of Price Administration. ${ }^{354}$ In Bowles v. Willingham, the Court upheld a broad delegation of rent control power to the Price Administrator under the Emergency Price Control Act of 1942. ${ }^{355}$ In Hirabayashiv. United States, the Court upheld a curfew imposed in the wake of the Japanese attack on Pearl Harbor by the government upon individuals of Japanese descent living in the United States. ${ }^{356}$ Finally, in Korematsu v. United States, the Court upheld the authority of the United States government to exclude Japanese Americans from areas deemed critical to national defense and potentially vulnerable to espionage. ${ }^{357}$

Appellate judges at the circuit courts of appeals almost all agreed with the Bush Administration's analysis of the President's Commander in Chief authority under the Constitution in the four cases discussed above. ${ }^{358}$ Eleven of twelve circuit court judges applied the same precedents as the government and reached the same conclusion as the government. The circuit courts deferred to

349. See infra text accompanying notes 350-57.

350. See BRIAN MCGINTY, LINCOLN AND THE COURT 9, 302-09 (2008).

351. See Korematsu v. United States, 323 U.S. 214, 214 (1944); Yakus v. United States, 321 U.S. 414, 424-25 (1944); Bowles v. Willingham, 321 U.S. 503, 511 -12 (1944); Hirabayashi v. United States, 320 U.S. 81, 93-94 (1943); Ex Parte Quirin, 317 U.S. 1, 1 (1942); United States v. Bethlehem Steel Corp., 315 U.S. 289, 304-05 (1942).

352. See Ex Parte Quirin, 317 U.S. at 1.

353. See Bethlehem Steel Corp., 315 U.S. at 309.

354. See Yakus, 321 U.S. at 423-24.

355. See Bowles, 321 U.S. at 510-11.

356. See Hirabayashi, 320 U.S. at 91-92.

357. Korematsu v. United States, 323 U.S. 214, 218 (1944).

358. See Boumediene v. Bush, 476 F.3d 981, 994 (D.C. Cir. 2007); Al Odah v. United States, 321 F.3d 1134,1136 (D.C. Cir. 2003); Hamdi v. Rumsfeld, 316 F.3d 450, 463 (4th Cir. 2003). 
the elected branches of government. ${ }^{359}$ That has not been true with respect to the Supreme Court. ${ }^{360}$

Lawyers in the Bush Administration looked to the World War II era precedent when advising the President and other decision makers. Like the attack on Pearl Harbor in 1941, the United States suffered a devastating attack on our homeland on September 11th. Congress declared war following the attack on Pearl Harbor. ${ }^{361}$ Here, Congress passed an AUMF resolution providing a broad grant of authority to the President to use military force. ${ }^{362}$ Unlike the deference shown to President Roosevelt by the Supreme Court during World War II, however, this Court has shown little inclination to defer to Congress or the President. Why? Perhaps we failed to recognize the significance of changes in the legal and political landscape since World War II-changes such as the Geneva Conventions and the Uniform Code of Military Justice. One reason cited for the Supreme Court's muscular response is the mistakes in detention policies. Regrettably, in virtually every conflict innocent people are mistakenly detained. Given the nature in which al Qaeda and the Taliban fight in violation of the laws of war, the resulting detainment of innocent people is not surprising. From the beginning of the fighting in Afghanistan, the U.S. government engaged in extraordinary efforts to minimize such mistakes.

Take, for example, the thorough process for determining enemy combatant status. $^{363}$ The process has evolved over time, but a snapshot taken in March 2004 would have shown the following: Immediately upon capture, (1) American soldiers make an initial assessment in the field and detain those who are posing a threat to the United States and coalition forces based on available information or direct combat. ${ }^{364}$ After the initial battlefield assessment, detainees are sent to a centralized holding area; (2) a military screening team at the central holding area reviews available information, including interviews with the detainees. ${ }^{365}$ Advised by military lawyers, intelligence officers, and federal law enforcement officials, the military screening team assesses whether detainment should continue for the detainee and whether transfer to Guantanamo is warranted; (3) a general officer, designated by the combatant commander, makes a third assessment of those enemy combatants recommended for transfer to Guantanamo - considering the

359. See cases cited supra note 358 .

360. See Boumediene v. Bush, 128 S. Ct. 2229, $2272-73$ (2008); Hamdan v. Rumsfeld, 548 U.S. 557, 591 -92 (2006), superseded as recognized in Rasul v. Myers, 512 F.3d 644 (D.C. Cir. 2008); Rasul v. Bush, 542 U.S. 466, 487 (2004), superseded by statute as recognized in Myers, 512 F.3d at 644; Hamdi v. Rumsfeld, 542 U.S. 507, $581-82$ (2004).

361. See S.J. Res. 116, 77th Cong. (1941).

362. See Authorization for Use of Military Force, S.J. Res. 23, 107th Cong. (2001).

363. See infra text accompanying notes 364-68.

364. See generally Dep't of Def., Fact Sheet: Process for Determining Guantanamo Detainees, available at http://www.defense.gov/news/Jan2006/d20060215detaineeprocesses.pdf (discussing review tribunal processes taken to determine enemy combatant status in Guantanamo).

365. See id. 
threat posed by the detainee, his seniority within hostile forces, possible intelligence that may be gained from the detainee through questioning, and any other relevant factors; (4) Department of Defense officials in Washington also review those proposed for transfer to Guantanamo. ${ }^{366}$ An internal Department of Defense review panel, including legal advisors, reviews the recommendations of the combatant commander and advises the Secretary of Defense on proposed detainee movements to Guantanamo; (5) after the Secretary of Defense approves the recommendations, the detainee is transferred to Guantanamo; and (6) immediately upon arrival, detainees are interviewed and further assessments are made. ${ }^{367}$ The review of detainees is based on all relevant information, including information derived from the field, detainee interviews, U.S. intelligence and law enforcement sources, and information from foreign governments. The examination of detainee information is a very thorough, almost painstaking process-far more process than prisoners of war are entitled to receive under the Geneva Conventions. ${ }^{368}$

Despite the care exercised in correctly identifying enemy combatants, our government made mistakes. In this new unconventional conflict, our enemies wage war in our neighborhoods and over the Internet. They fight wearing civilian clothes. They do not wear a uniform or openly carry a weapon. Difficulties exist in telling the bad guys from the good guys. Any mistake is regrettable, but mistakes here are magnified because of the possible lengthy duration of hostilities with al Qaeda, creating the danger that an innocent person is mistakenly detained for a long period of time. While no one knew with certainty when previous conflicts would end, the age of terrorism appears to be with us for the foreseeable future. The battlefield will likely resurface here within our borders, and it will involve American citizens acting either alone or in concert with others overseas. Under these circumstances, perhaps some judges feel the judiciary has an added responsibility to ensure that only the guilty are detained. Some scholars believe President Bush's blanket determination that all members of the Taliban are not entitled to prisoner of war protections has added to the possibility of mistaken identity. ${ }^{369}$ In essence, this decision dispensed with the need to make battlefield status determinations by a competent tribunal as required under Article 5 of the Geneva Conventions whenever there is any question about the appropriate status of a detainee. ${ }^{370}$

Such criticism fails to recognize the enormous efforts, some of which are discussed above, undertaken by the Bush Administration - and continued now by the Obama Administration - to properly identify and detain only enemy

366. See id.

367. See id.

368. See Third Geneva Convention, supra note 57, at art. 5.

369. See Manooher Mofidi \& Amy E. Eckert, "Unlawful Combatant" or "Prisoners of War": The Law and Politics of Labels, 36 CORNELL INT'L L.J. 59, 81 (2003).

370. See Third Geneva Convention, supra note 57, at art. 5. 
combatants. ${ }^{371}$ Scholarly criticism also fails to recognize that, when mistakes have been identified, corrective action was taken as soon as possible. ${ }^{372}$ Hundreds of captured individuals have been released from Guantanamo and thousands more released from detention facilities in Afghanistan. ${ }^{373}$ President Bush often said that he did not want the United States to be the world's jailer. ${ }^{374}$ Nor did they want to detain innocent people. These are the reasons why the U.S. government has taken such extraordinary steps to protect the innocent.

A second reason there may be less deference to the political branches today is because of negative public opinion over some aspects of the war on terror. The conflict in Iraq is unquestionably unpopular. The fighting in Afghanistan is becoming more unpopular. In his book "The Supreme Court," Chief Justice William Rehnquist wrote about the 1952 Supreme Court case Youngstown Sheet \& Tube Co. v. Sawyer and the role of the Court in a time of war. ${ }^{375}$ The case addressed the President's constitutional power to seize American steel mills. ${ }^{376}$ After negotiations on collective bargaining terms and conditions failed, the United Steel Workers of America gave notice of intent to strike. ${ }^{377}$ President Truman believed a nationwide steelworker strike would jeopardize national security, for steel was an indispensible component of weapons and other Korean War supplies. ${ }^{378}$ The President ordered the Secretary of Commerce to seize the steel mills and continue production. ${ }^{379}$ Rehnquist, who was a clerk to Justice Jackson at the time, discusses in his book how the Court found that President Truman had exceeded his authority. ${ }^{380}$ According to the majority, there was no basis in the law or the Constitution for the President's actions.

Interestingly, the Chief Justice speculates that if the seizure had occurred during World War II, when there was strong public support for the war and greater trust for the Commander in Chief, the government would likely have prevailed under the President's war powers authority. ${ }^{382}$ At the time the justices were deciding Youngstown, in contrast, the public was ambivalent about the Korean conflict and public support for Truman was not strong. ${ }^{383}$

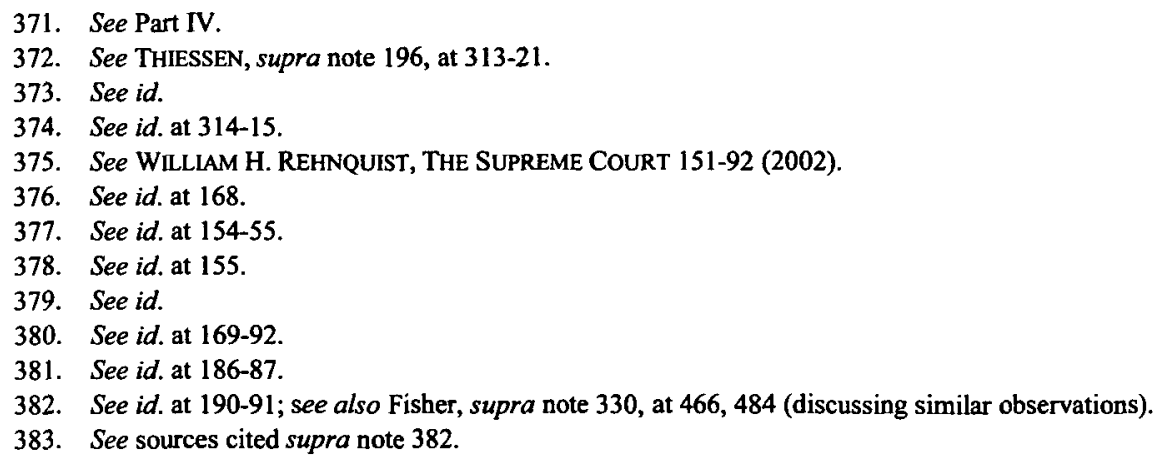


Chief Justice Rehnquist candidly acknowledges in his book that public opinion matters to judges. ${ }^{384}$ He believed public opinion made a difference in the steel seizure war powers case. Some believe public opinion has also affected members of the current court. ${ }^{385}$ Imagine if the four major terrorism cases discussed above had been presented to the Court before the Iraq invasion in $2003{ }^{386}$ Would the outcome of the cases have been different? What if they had been decided within a year following the September 11 th attacks, when the American public feared another attack from within our borders by individuals living in America? Would the Court have been more deferential to the President and the Congress?

\section{CONCLUSION}

The September 11, 2001, attacks and the deaths of over 3,000 innocent Americans elicited a strong response from the Bush Administration and Congress. In order to successfully fight an unconventional war against a new type of enemy, our government took extraordinary steps to protect Americasteps that often tested the limits of our domestic and international legal obligations. Some scholars have suggested that lawyers were too involved in formulating these steps, that they had too much influence on policy. ${ }^{387}$ I disagree. Attention to the legal issues was absolutely necessary and appropriate given the circumstances. After September 11, 2001, it seemed as if I spent at least fourteen hours a day, every day, for months either in White House meetings with lawyers dissecting the provisions of a statute or treaty, or in meetings with decision makers, explaining the legal ramifications of various policy options. I am not aware of any major terrorism policy undertaken by the Bush Administration that was not fully examined and reexamined for legality by the lawyers. President Bush wanted the policy makers to be aggressive on behalf of the American people, but he expected the lawyers to keep the policy makers on the right side of the law. This meant getting legal guidance from the Justice Department. We wanted to get it right. Military soldiers, CIA operatives, law enforcement agents, and NSA analysts were risking their lives and careers to protect America. I felt a deep obligation to give my best judgment about what the law allowed.

Unquestionably, our legal conclusions could have an effect on policy, and in some cases, it might foreclose options. I worked diligently, however, to put aside my policy preferences so that my legal conclusions were not intended to support one option over another as a matter of policy, or to foreclose an option entirely. I have no reason to doubt that other Administration lawyers discharged their responsibilities any differently. If I had had such doubts, I

384. See REHNQUIST, supra note 375, at 192.

385. See id.

386. See supra Part VI.

387. See MAYER, supra note 149 , at 147. 
would have questioned the lawyer about their advice and asked that the lawyer not be included in further discussions.

There was, at times, serious disagreement between the lawyers over the scope of our government's legal obligations. ${ }^{388}$ Most of the time, we got it right. Sometimes we did not, but it was not for lack of effort. I know of no circumstances in which government lawyers acted in bad faith, gave advice under pressure from the client, or willfully provided the wrong advice. ${ }^{389}$ To the contrary, the lawyers worked hard, sometimes under extreme pressure, to provide the correct legal guidance that would shape the President's efforts to protect our country. ${ }^{390}$ Disagreements between lawyers over such issues are a good thing, not a bad thing. ${ }^{391}$ And disagreements do not always signal that a Presidential decision is wrong; it may simply signal that the decision was hard. ${ }^{392}$ The fact that there was disagreement then, and that debates continue today, should not be surprising or unexpected. These are important issues, worthy of debate. Such discussions, when done in the context of the environment that existed at the time of the advice, are a necessary check in ensuring that the actions of our government are consistent with the rule of law. And, lawyers play one of the most important roles within our legal and political system in protecting the precious rights embodied in the words of the Constitution.

Because the President expected our conduct to always conform to the law, OLC was constantly revisiting and reevaluating the advice it had given on terrorism issues. From time to time that advice changed based on different or newly discovered facts or new court decisions. Sometimes just having another lawyer reexamine an issue was helpful in rethinking the best approaches and solutions to a legal problem.

I welcomed the considered review and reevaluation of the legal issues by Administration lawyers, and I was not surprised that our legal position shifted over time. The law is not static, and I do not believe that our interpretation of the law should necessarily remain static any more than I would expect the Supreme Court's interpretation of the Constitution to never change. To the contrary, because of the difficulty and sensitivity of the terrorism-related issues we examined, I would have been surprised if there had been no changes in our legal position from late 2001 until the time I left government in the fall of 2007. Updating or correcting legal advice based on changed circumstances or changes

388. See Memorandum from David Margolis, Assoc. Deputy Attorney Gen., to Eric Holder, U.S. Attorney Gen. on the Cent. Intelligence Agency's Use of "Enhanced Interrogation Techniques" on Suspected Terrorists (Jan. 5, 2010), available at http:/www.scribd.com/doc/27134684/David-Margolis-Memo-OnTorture-Memo-Report.

389. But see DOJ Report on Bush Administration Interrogation Memos and Related Documents, http://judiciary.house.gov/issues/issues_OPRReport.html.

390. See also GoLDSMITH, supra note 42, at 32, 36.

391. See id.

392. See id. 
in the law was a good thing, it was the responsible thing to do and inspired confidence in the work of OLC.

I was sensitive to those in the Administration, however, including the President, who became frustrated that the lawyers repeatedly changed their legal conclusions. Generally, I strongly supported a legitimate review of previous legal opinions. When I became Attorney General, for example, I insisted on an OLC review of certain terrorism-related opinions. But as the War on Terror became more controversial, I worried that some Administration lawyers might be backing away from previous legal guidance because the policy had become either controversial or unpopular. If a legal opinion is wrong or incomplete, then it should be withdrawn or corrected. But an opinion should not be withdrawn or changed because of disagreements over policy. I worried about possible legal exposure to law enforcement and intelligence agents and operators who had relied in good faith upon the Department's advice. Yes, they could assert the previous guidance as a defense to prosecution, but they would have to incur the costs of a lawyer to assert it. Similar concerns by members of Congress undoubtedly led to the provisions in the DTA and the MCA providing a statutory defense in any civil action or criminal prosecution to those acting in good faith according to practices officially authorized and determined to be lawful. I also worried about the political fallout that follows a change in legal analysis on controversial policies. As we have seen time and again, the political enemies of a president will use the new guidance to support their claims that the Administration's previous acts were outside the law.

I was concerned too, that the President and the other policy makers would begin to question whether we lawyers knew what we were doing by constantly changing our legal position. For these reasons, I raised tough questions whenever OLC changed its legal position. I asked questions not to pressure DOJ lawyers to change their position, but to test their conviction and to fully understand the motivation behind the change.

Fall 2011 will be the ten-year anniversary of the September 11 th attacks. So much changed that day-lives were lost, and our way of life was transformed permanently. The innocence of America that existed on September 10,2001 is gone. I wish we could have it back, but we cannot.

As I travel the country, I see that Americans have moved on and are living their lives in the new norm. The inconvenience of security measures, such as taking off our belts and shoes at the airport, is the price we pay for living in a free and open society. Most Americans understand and accept it.

Our enemy is smart and patient. They watch what we do as a country, and they adapt their tactics in response to our measures. In turn, the U.S. government will do what is necessary to protect Americans. Whenever that happens, government lawyers will be involved to ensure that the development of policy is consistent with our domestic and international legal obligations. 
Throughout history, the American people have looked to the President to defend our country in times of crises. I believe, however, that most Americans-and certainly the critics of a President-want to be reassured that the majestic power of the Presidency is constrained by law even in times of war. Our allies too want to be reassured that the United States, the most powerful country in the world, is limited by some law in its use of power. As we tried to do in the months and years following the September 11 th attacks, current and future government lawyers will play a critical role in defining those limits based upon their best interpretation of our Constitution, congressional statutes, treaties, relevant case law, and historical practice and precedent.

Americans still live in the greatest country on the face of the earth. Our continued safety in a free and open society is a testament to the policies of Congress and the President, and to the effective execution of those policies. I am proud of my service to our country and am privileged to have played a role in helping secure our national security. 


$$
\text { . }
$$

